\title{
IDÉIAS
}

los ou concepções de racionalidade não ajustáveis à realidade brasileira;

* atuaçáo preterencial sobre os meios, não estando voltadas para o objetivo de instrumentação das políticas do setor público;

* falta de um sentido de estratégia que permitisse a viabilidade de projetos dentro de um esquema de superação de resistências, acomodação de conflitos, adequação aos recursos disponíveis e determinação de finalidades no tempo.

Reforma Administrativa é uma tomada de consciência, por parte de dirigentes e dirigidos, da necessidade de modernizar o quadro governamental.

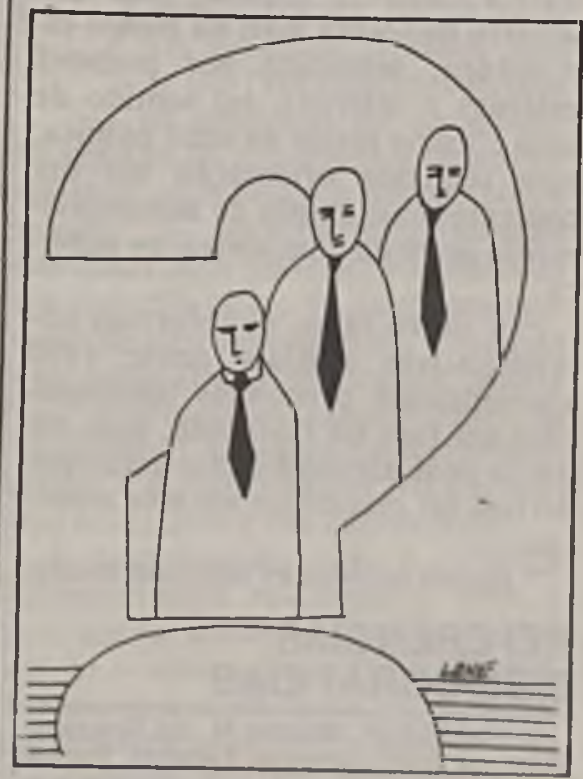

Foi por compreender bem esse problema e atendendo a uma demanda social por maior eficiência e eficácia no Governo que o presidente José Sarney decidiu, em meados do ano passado, iniciar um novo processo de reforma administrativa.

Através dos Decretos $n^{\prime s} 91.300$ de 04 de junho de 1985 e 91.501 de 31 de julho de 1985, determinou ao ministro Aluizio Alves fosse iniciada uma ampla reforma da Administração Pública Federal sob a liderança do Ministério da Administraçào. E o objetivo claramente definido, desde o inicio, nos documentos de diretrizes e nos pronunciamentos do Ministro da Administracão é o de "preparar a Administração para o novo regime democrático e particularmente, para execução do Plano Nacional de Desenvolvimento do governo José Sarney".

\section{Desenvolvimento, capacidade e reforma administrativa}

\author{
Por Gerald E. Caiden "
}

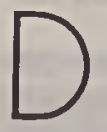

esde o inicio dos anos 50, a modernização administrativa vem sendo cada vez mais reconhecida como parte integrante do processo de desenvolvimento. A capacidade de assumir novas tarefas, lidar com complexidade, compreender o conflito, solucionar novos problemas, mobilizar recursos, aprender com a experiência e a incerteza e lidar com crises e turbulências depende de uma capacidade administrativa significativamente ampliada, baseada em grande parte em maior profissionalização, burocratização, mecanizacão c talento administrativo. Como os sistemas administrativos mudam lentamente e de maneira conservadoramente crescente, a reação e a adaptação naturais são inadequadas para se enfrentarem os desafios do desenvolvimento. É necessário algo mais rípido e mais radical: programas organizados de reforma administrativa nos principais setores de desenvolvimento, particularmente nos canais de menor reação, mais entorpecidos, que tolhem o progresso e os esforços de desenvolvimento em outros pontos.

O freio administrativo ao desenvolvimento é reconhecido universalmente. Durante as últimas duas décadas, vários paises cuja capacidade administrativa deve ser altamente considerada segundo quaisquer critérios instigaram amplas revisões de seu mecanismo de Governo, do desempenho das empresas públicas e do setor privado e anunciaram pla-

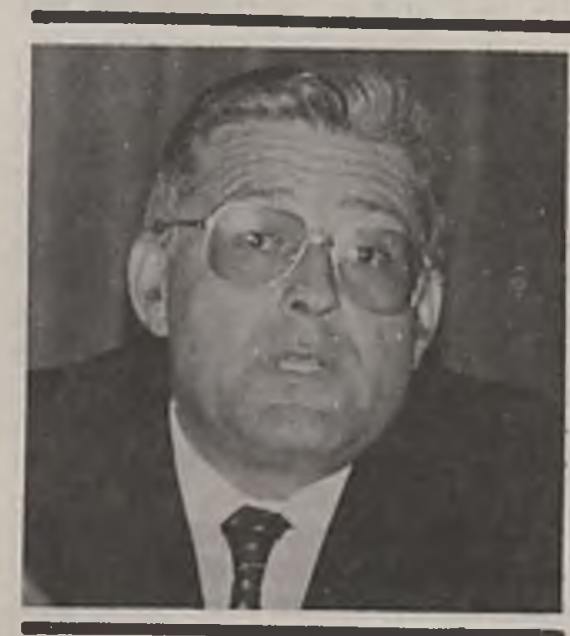

nos para um exame estrutural e rápida expansão do ensino e do treinamento administrativos. Um número impressionante de novos estados obsedados com os problemas de sobrevivência, instabilidade e pobreza da sociedade alterou radicalmente seus sistemas administrativos ou chamou especialistas estrangeiros para dar. orientação a respeito da consecução de substancial melhoria no desempenho administrativo. Órgãos internacionais e multinacionais foram instados a fornecer assistência e ajuda em projetos de reformas setoriais e administrativas e atenderam dentro das limitaçes de seus meios. Tornou-se cada vez mais evidente que os conhecimentos e a experiência pertinentes eram escassos e inadequados. Como resultado, a assistência à ampliação da capacidade administrativa e à melhoria dos pro-

- Prolessor e conferencisla, diretor do Departamento de Ciência Politica da Universidade de Haifa, Estados Unidos, Caiden esleve recentemente no Brasil, onde pronunciou uma série de palestras, inclusive esta na Fundação-Centro de Formaçăo do Servidor Publico, Funcep, em Brasilia, cujo texto se publica a seguir, por seu valor como visáo universal dos esforços de modernizacăo e reforma dos servicos públicos, em vários paises. 


\section{IDÉIAS}

gramas de reforma administrativa tornou-se uma prioridade da Segunda Década de Desenvolvimento das Nações Unidas.

... O que se requer em muitos paises em desenvolvimento é uma "revolução administrativa" em apoio a mudanças revolucionárias nos campos econômico e social na Segunda Década de Desenvolvimento das Nações Unidas... A administração pública precisa ser recriada, renovada e revitalizada para produzir as mudanças e as realizações requeridas na transformação das sociedades. Isto necessita de uma espécie e uma magnitude diferente de capacidade administrativa... $\mathrm{O}$ desafio e a tarefa dos anos 70 é conceber e instalar sistemas administrativos que possam realmente acelerar o desenvolvimento e melhor permitir que os paises em desenvolvimento façam uso efetivo de seus recursos... As estruturas, sistemas e práticas administrativas disfuncionais precisam ser substituidas. Bastarão organizaçōes dinâmicas, uma administração atilada e processos administrativos atualizados... Tornam-se indispensáveis uma nova concentração na consecução de objetivos e uma capacidade de solucionar problemas operacionais complexos... A administração no sentido do desenvolvimento requer, assim, empenho e capacidade na execução de planos, programas e projetos. Precisa eliminar obstáculos à ação, mobilizar mão-de-obra, materiais e equipamento, por exemplo, para erguer uma nova instalação, prestar um serviço, pôr em execução um programa, e precisa fazer tudo isto efetivamente e com rapidez (1).

Os retardamentos e a obsolescência administrativos e a conseqüente necessidade de "cirurgia" e "terapia" administrativas são problemas de amplitude mundial... E necessário enorme volume de reforma e melhoria para o desenvolvimento de estruturas e sistemas administrativos essenciais à execução de planos de desenvolvimento e outras medidas para a aceleraça do progresso social e econômico. A alta prioridade atribuida a este esforço (pelo Secretário-Geral) é endossada, dando atenção especial à:

(a) Formulação de requisitos básicos para a melhoria da administra- ção desenvolvimentista de paises isolados e de grupos de paises com caracteristicas similares;

(b) Análise e formulação de estratégias e métodos para tornar a reforma e a melhoria administrativas um processo continuo e bem-sucedido;

(c) Preparacão de linhas mestras e assistência, tal como sejam solicitadas, no estabelecimento de órgãos centrais efetivos de reforma e meIhoria administrativas;

(d) Concentração dos esforços de reforma na criação de habilitaçóes para a consecução de objetivos de desenvolvimento e na melhor administração dos esforços de desenvolvimento (2).

Esta descoberta relativamente recente da reforma administrativa inslitucionalizada é devida, em parte, a uma reavaliação do significado do desenvolvimento. As concepções

\begin{tabular}{|c|}
\hline As necessidades de \\
"cirurgia" c "terapia" \\
administrativas \\
são problemas de \\
amplitude mundial. \\
É preciso um \\
grande volume de \\
reformas e melhoria \\
das estruturas e \\
sistemas essenciais \\
à execucão de \\
planos de \\
desenvolvimento \\
social e econômico.
\end{tabular}

iniciais das diferenças quantitativas entre paises ricos e pobres, estados avançados e atrasados, sociedades desenvolvidas e subdesenvolvidas (ou $\mathrm{cm}$ desenvolvimento), civilizações pós-industrializadas e préindustrializadas foram revistas por necessidade à medida que os paises ricos, avançados, desenvolvidos, industriais se viram a braços com problemas próprios de desenvolvimento c os paises pobres, atrasados, subdesenvolvidos, não industriais não se viram, qualitativamente, em situação muito má, afinal de contas. Uma atenção cada vez maior tem sido dedicada aos "aspectos estrutu- rais de cada sistema, a suas ligações e sua lógica internas e a seu desempenho ou sua capacidade de reagir a estimulo" (3), concentrando-se na produtividade do trabalho, no crescimento setorial e na mudança de sistemas, na movimentação da sociedade e na mobilização social, assim como na mecânica do trato da mudança social. Bem recentemente, o desenvolvimento passou a ser visto como a fuga da pobreza da sociedade através de processos de modernização ou, mais simplesmente, como a capacidade da sociedade de transformar aspiraçōes, energia e recursos disponiveis em beneficios langiveis e estéticos, particularmente esperança de vida mais longa, padrão de vida mais alto, trabalho significativo, segurança pessoal e expressão mais livre da individualidade, empregando ciência e tecnologia, espirito empreendedor, capital humano, comunicações e engenho organizacional. A capacidade de conseguir que as coisas desejadas em termos de coletividade sejam feitas com o minimo de desperdicio, violência, ruptura e disfunção é capacidade administrativa. As exigências administrativas de uma pequena e isolada sociedade rural nômade são minimas, já que as reivindicacões são poucas e os meios de satisfação delas são fixos e invariáveis. Sua capacidade administrativa é baixa, mas o mesmo acontece com suas necessidades. As comunidades metropolitanas da atual ordem mundial, com informações instantâneas via meios de comunicação de massa, têm capacidade administrativa muito maior, mas, em compensação, suas necessidades são de ordem cada vez maior.

Como a capacidade administrativa é, provavelmente, o aspecto menos percebido e menos tangivel do desenvolvimento em comparação com o que há de novo em tecnologia, formação de capital, engenho artistico individual e instituições politicas estáveis mas decisivas, $\dot{e}$, potencialmente, o que fica mais de lado e o menos mensurável ou identificável. Contudo, recuando-se na história da civilização, nenhum dos grandes marcos poderia ter sido conseguido sem substancial capacidade administrativa. A formação de grandes cidades e obras públicas, a 


\section{IDÉIAS}

governanca de impérios enormes, a direção de grandes exércitos e a construção das maravilhas do mundo e dos grandes santuários religiosos - tudo isto envolveu a reunião de muitas pessoas e muitos recursos de acordo com planos preconcebidos sobre a extensão dos prazos e requereu normas comuns de trabalho, de inspeça apropriada e de exame do trabalho, tomadas de decisðes de alta qualidade, correção de erros descentralizada e técnicas administrativas improvisadas. Exigiu experiência no trabalho com organização de grande escala em condições dificeis e penosas e apoiou-se no engenho organizacional sem ajudas técnicas modernas. Alguns feitos da engenharia ainda nos intrigam. Infelizmente, giande parte dos registros administrativos está perdida, mas pelos esparsos remanescentes que sobreviveram sabemos que civilizaçōes passadas conceberam códigos administrativos, organizaçōes burocráticas e técnicas de administração notavelmente parecidos com os nossos. Certamente, a mecânica da organização, da elaboração orçamentária e da supervisão de pessoal era conhecida. Mas em certa-época ambições superaram sua capacidade de desenvolvimento e seu engenho organizacional ou então elas negligenciaram a'manutenção de sua capacidade administrativa. Elas foram alcançadas por outras socicdades com maiores vantagens naturais e talentos administrativos superiores ou, mais provavelmente, com noções diferentes de conduta social c desenvolvimento, agora consideradas de nivel inferior.

A perspectiva historica lambem nos permite ver que ate mesmo nas condiços mais favoráveis - ricos recursos, auto-suficiência, uma ética de trabalho, austeridade e autosacrificio para o investimento, alta instrução - algumas sociedades deixaram de atingir sua potencialidade plena ou alcançar niveis ainda maiores de realizaça porque careciam da capacidade administrativa necessária. Não davam valor a seus recursos naturais ou não sabiam o que fazer com eles ou, ainda, os exploravam até a exaustão sem buscarem alternativas e sucedâneos e sem preocupação com a conservação. Não eram organizadas para conce-

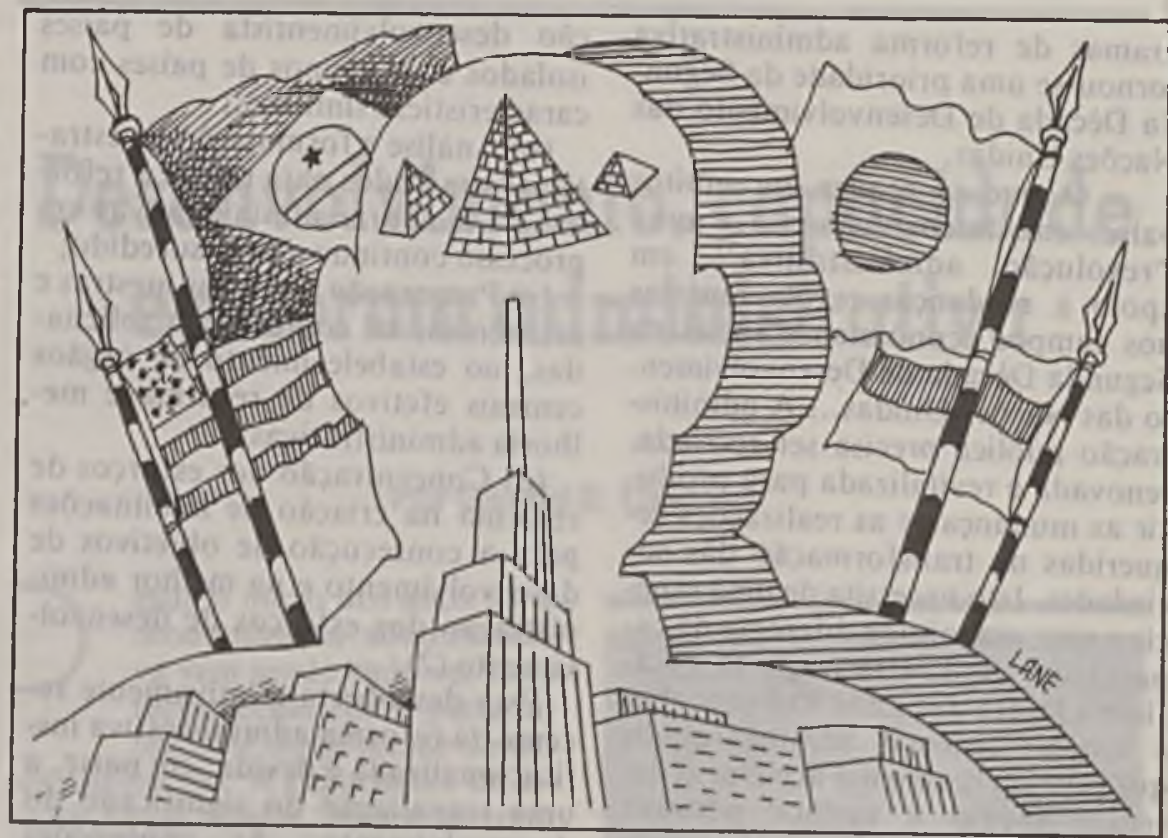

\begin{tabular}{|c|}
\hline Muitas nações \\
deixaram de \\
atingir grandes \\
culminâncias \\
por falta de \\
administradores \\
capazes. Porque \\
não deram valor \\
a seus recursos \\
naturais ou não \\
sabiamo que fazer \\
com eles. Idéias e \\
talentos foram \\
desperdicados.
\end{tabular}

ber nova tecnologia ou para tirar proveito dos conhecimentos existentes. Havia insuficiência de investimentos, experimentação, pesquisa e novos conhecimentos. O engenho individual era desperdiçado - negligenciado, deixado de lado, suprimido, desencorajado. As idéias e os produtos do talento criativo eram ridicularizados e acabavam perdidos. Elas careciam da disposição e da capacidade de explorar ou universalizar a inovação. Os arranjos institucionais eram imprestáveis, em grande parte repressivos, reacionários, conservadores, provincianos, divergentes e inseguros. Muito esforço e auto-sacrificio era desperdicado em coisas inúteis e desnecessárias, objetivos contraditórios e ações espoliadoras. Em suma, a cultura administrativa - a maneira com que uma sociedade se comporta em relação a seus interesses - era inadequada para as tarefas impostas a ela, os sistemas administrativos não podiam funcionar apropriadamente e os administradores careciam das habilitacões e do ambiente necessários para um desempenho adequado. Durante periodos apreciáveis, outras vantagens compensaram com vantagem as deficiências administrativas, mas sua potencialidade de desenvolvimento era restrita e em épocas de crise e turbulência elas entravam em colapso.

A capacidade administrativa não pode ser lida como certa. Não nasce em resposta a necessidades. Nem sempre a necessidade é a mãe da inovação administrativa. Uma sociedade tem de trabalhar arduamente para obter competencia administrativa. Felizmente, o engenho organizaçional surge nos lugares mais imprevistos, nas circunstâncias menos promissoras, e não depende de atribuiçâo, instrução ou experiência. A capacidade administrativa difere acentuadamente entre os individuos: alguns têm uın discernimento instintivo, natural, enquanto outros não são capazes de captar os rudimentos da administraçao. Historicamente, também, parece ter havido acentuadas diferenças na capa- 


\section{IDÉIAS}

cidade administrativa entre as sociedades. Umas caminharam às tontas, atingindo objetivos de qualquer jeito durante séculos, enquanto outras parecem ter estado sempre no topo do que estavam fazendo e capazes de transmitir seu talento administrativo de uma geração para outra. Umas acalentaram e protegeram o povo com um discernimento instintivo de administração, enquanto outras suprimiram a criatividade administrativa através de sistemas de classe rígidos, imóveis. Umas tiveram de apoiar-se unicamente na tradição oral e de redescobrir continuamente o know-how administrativo, enquanto outras se beneficiaram do acesso a registros escritos acumulados e puderam crescer continuamente em cima da experiência do passado. Mesmo assim, sociedades cujos membros, coletiva ou individualmente, pareciam possuir um discernimento administrativo instintivo acima da média foram alcançadas por sociedades menos dotadas, administrativamente, mas que trabaIharam para melhorar sua capacidade e seu desempenho administrativos e tiraram proveito da negligência, do alheiamento e da displicência das outras. Hoje, alguns paises têm decidida agudeza em capacidade administrativa, mas não têm monopólio do engenho organizacional $e$, a menos que continuem a trabalhar para manter seu desempenho administrativo, poderão ser alcançados por paises que tiram proveito de todos os meios disponiveis para melhorarem seus sistemas administrativos. Faz algum tcmpo, no campo da inovação técnica, vem-se compreendendo que a capacidade administrativa de explorar uma invenção de modo barato e rápido talvez valha mais do que a capacidade inata de inventar.

\section{A BUSCA DE CAPACIDADE AD- MINISTRATIVA}

Para aumentar a capacidade administrativa, foi dada a partida para identificá-la e medi-la. Tal como acontece com muitos termos usados nas ciências sociais, nảo há acordo em seu uso e nas conflitantes interpretações de seu significado, que acentuam sua natureza bem efêmera e seu conteúdo de mudança. A Divi- são de Administração Pública da Organização das Nações Unidas prefere que a expressão "capacidade administrativa" descreva esforcos para a melhoria de sistemas administrativos com o fim de servir a necessidades de desenvolvimento, mais particularmente a viabilidade administrativa de planos, programas e projelos e a eliminação de obstáculos à modernização adminisirativa - o como fazer as coisas. Numa tentativa preliminar de definição, a capacidade administrativa foi encarada "como a capacidade de obter resultados pretendidos através de organizaçōes", levando em conta a natureza das tarefas estabelecidas, os arranjos à mão para o cumprimento das tarefas e o ambiente no qual as tarefas são estabelecidas e os arranjos feitos. Qualquer tentativa

\begin{tabular}{|c|}
\hline Algumas sociedades \\
tiveram de \\
apoiar-se na tradição \\
oral e de redescobrir \\
know-how administrativo \\
e tiraram proveito \\
da negligência edo \\
alheiamento das \\
outras. E ainda outras \\
podem perder lugar \\
para os povos que \\
sabem usar do \\
engenho e arte \\
de administrar.
\end{tabular}

de avaliá-la estaria na natureza de afirmações de probabilidade "fornecidas por informações ou estimalivas sobre desempenho futuro à luz das forças e fraquezas da estrulura (de uma organização) e das contencōes e oportunidades oferecidas por seu ambiente" (4).

1. O desempenho é fundamental. E necessário saber a espécie, a quantidade e a qualidade dos serviços fornecidos, os custos do fornecimento de tais serviços, os beneficios e os danos que fluem do fornecimento deles a tais custos e também saber como niudar a relação beneficio-fornecimento-custo, tanto diretamente quanto pela mudança da estrutura ou do ambiente.
2. A estrutura consiste em pessoas e recursos não humanos tal como estão organizados dentro de vários subsistemas com certas especies de relaçōes internas entre eles e que funcionam sob a influência de vários códigos e de certa espécie de mecanismo de orientação central. Estas variáveis estruturais, em seu contexto ambiental, fornecem a capacidade organizacional para várias espécies de desempenho.

3. O ambiente condiciona, legitima e fornece ou nega recursos a organizações e a sistemas grandes. $O$ desempenho $\dot{e}$ vitalmente afetado pelas relaçōes com o ambiente e até pela definição do ambiente. A agora rápida e turbulenta mudança em nosso ambiente apresenta um desafio muito grande para as organizaçōes c elas precisam adaptar-se.

Expressos nestes termos ou não, muitos esforços para melhorar a capacidade administrativa padecem do seguinte: mudanças estruturais colocadas enı execução com pouca atenção a suas implicaçōes para o desempenho; mudanças em métodos que não "compensam" com (óu que talvez ate impeçam) mais ou melhor produção; expansão ou meIhoria de certos serviços com atencão insuficiente aos custos ou benefícios; mudanças propostas ou efetuadas sem avaliaçōes realistas das atuais forcas e fraquezas (5).

$O$ resultado óbvio foi detalhar a avaliação da consecução de objetivos, do desempenho organizacional e das relaçōes ambientais.

A tentativa de identificar os fatores.-fundamentais da capacidade administrativa mostra-se dificil. Como a definição adotada reflete o caráter nebuloso das atividades administrativas, despende-se considerável esforço no esclarecimento de conceitos. A avaliação deverá ser estendida do setor público para o setor privado? A administração será uma variável dependente ou uma variável independente? Se ambas, como deverão ser distingüidos os dois aspectos? Quais serão as fronteiras das organizações, das atividades administrativas dentro delas e dos sistemas administrativos dos quais elas fazem parte? Os papeis dos setores público e privado poderão ser separados? Que peso deverá ser atribuido a cada fator? Como 


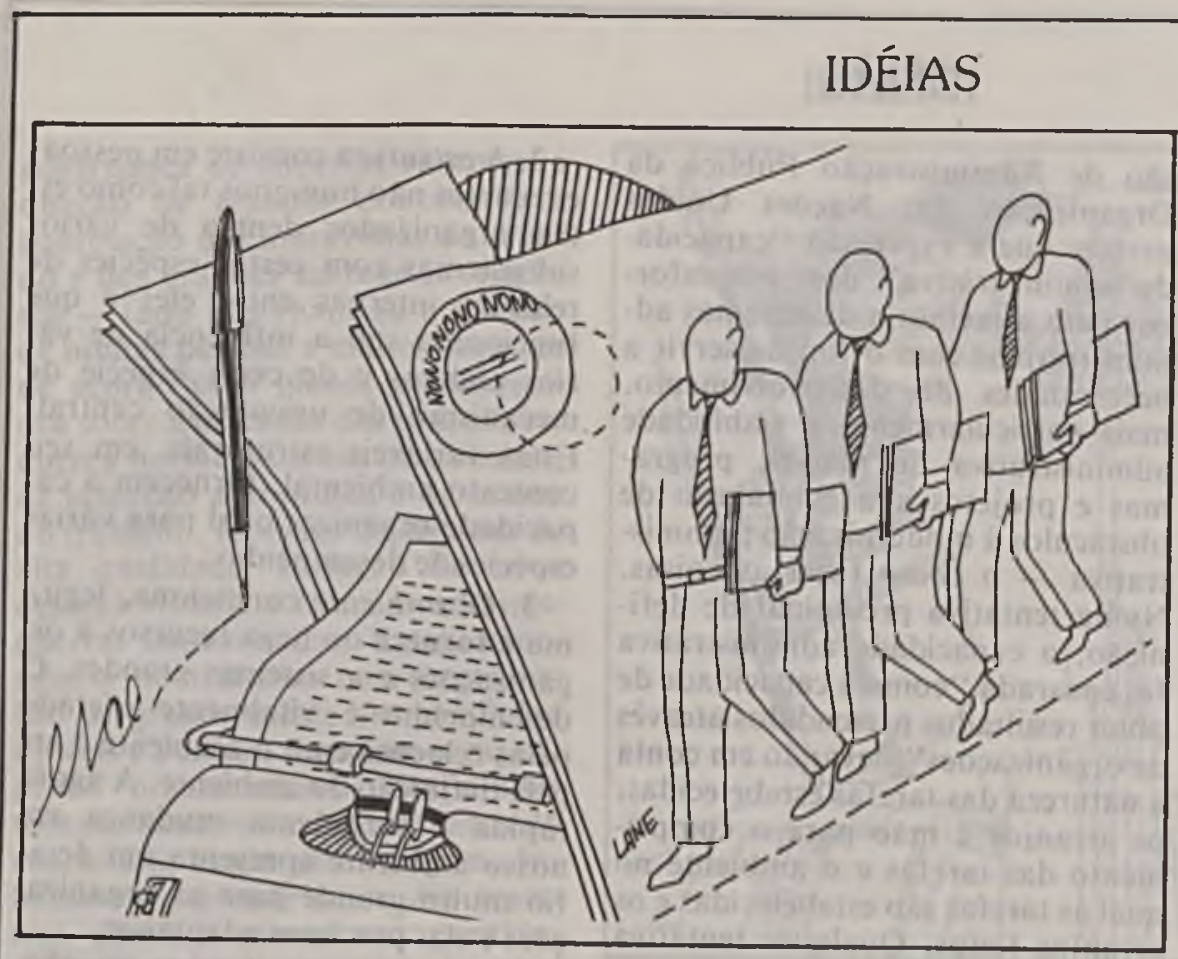

deverão ser obtidas, cotejadas e avaliadas as informações necessárias? O esforço de avaliação diminuirá os objetivos de melhoria? Deveremos colocar muita ênfase nos indicadores quantitativos em vez de nos indicadores qualitativos? Como deverão ser postos em ação os conceitos de custo, benefício, lucro, desempenho, etc.? Sob qual ponto de vista a capacidade administrativa deverá ser avaliada? Diante da falta de teorias, modelos e tipologias amplos tanto de administração como de desenvolvimento, pois continuam a ser acrescentados novos elos e novas relações, será prematuro o esforço de construir indicadores ilustrativos? Dado o fim do esforço inteiro, deverá haver uma distinçio entre "(a) sistemas administrativos que, quando melhorados, simplesmente se tornam servos mais eficientes de interesses que subordinam o desenvolvimento à preservacalo de suas próprias prerrogativas e seus proprios privilegios; e (b) sistcmas administrativos que precisam ser melhorados a fim de destruirem estruturas obsoletas e antiquadas que constituem obstáculo para o desenvolvimento cconômico e social (6)"?

Nåo será verdade que "quanto mais determinada situação requer reforma, menor è a capacidade uo mecanismo administrativo de executar medidas de reforma (7)"? E que quanto mais aumenta a capacidade adicional e mais difícil é gerá-la

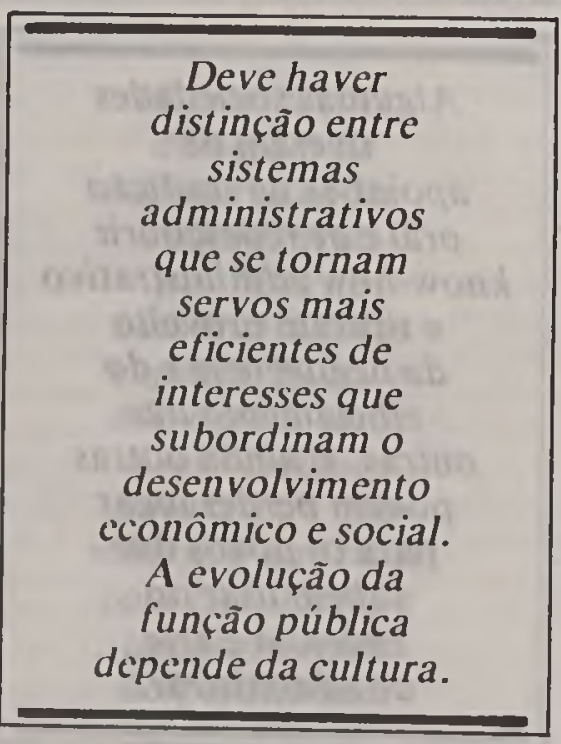

"por força da crescente sofisticação dos processos administrativos e da crescente variedade de idéias e modclos a serem considerados (8)"?

Importantes como são estas questơcs, sua interpretação da função administrativa no processo de desenvolvimento parece bem estreita. A evolução da função administrativa como um fenômeno social separado $\mathrm{c}$ distinto depende de certos pré-requisitos culturais. A sociedade precisa estar disposta a concentrarse no presente, isto é, preocupar-se com o aqui-e-agora em vez de com o passado acalentado ou o futuro anunciado. As crenças numa queda de alguma era dourada anterior ou no sacrificio do presente por recom- pensas em alguma pós-vida dourada futura têm de ser substituidas por uma firme conviccão de que a duração desta vida conta numa fuga imperativa da predominante pobreza da sociedade. $O$ entusiasmo que acompanha a identidade da terra natal, a ideologia coletivista, o racionalismo, o cientismo e o internacionalismo faz muito para a concentração de atenção no presente, mas a desilusão com o autogoverno, a rivalidade entre as grandes potências, a distância cada vez maior entre os paises ricos e os paises pobres e as disfunçð̄es da afluência pode levar à violência e ao escapismo nos paises ricos e ao fatalismo e à apatia nos paises pobres. A função administrativa necessita de um suporte ideológico - que vale a pena fazer coisas e fazê-las adequadamente; que coisas bem feitas mudam a sociedade para melhor e beneficiam todos os seus membros; que o tempo é um bem escasso e precioso, não algo infindável ou elástico a ser manipulado por autoconveniência; que a escassez é a situação humana perene; que o homem pode melhorar sua sorte ajudado por seu irreprimível impulso de competir e sobressair; que o progresso depende de sacrifício, energia e investimento em inovação; que a sociedade humana, resistente à adversidade, é capaz de revitalização e de auto-renovação. Tal suporte proporciona um senso de premência por trás da ação administrativa decidida. Dota os administradores de uma ética de trabalho otimista, um impulso essencial por trás do desempenho administrativo, particularmente sob tensão. Sua ausência é um convite aberto à má administração e ao desempenho fraco. Se ele não é incorporado de algum modo aos costumes culturais dominantes, tem de ser inculcado em lideres polenciais em seu papel como energizadores e movimentadores da sociedade. Por esta razão, ele é básico para a função administrativa e para quaisquer considerações de capacidade administrativa.

A função administrativa aparece quando os homens não vivem mais ao deus-dará, isto é, quando todos os esforços individuais não têm de ser devotados ao consumo imediato para a sobrevivência básica. A sociedade ou a cooperação social requer uma divisão do trabalho, espe- 
cialização de tarefas, papéis de tomada de decisões e assim por diante, mas num nivel baixo de desenvolvimento estes aspectos administrativos não podem ser dintinguidos ou separados de outros aspectos da sociedade. Na familia, é provável que o chefe da casa assuma responsabilidade pela função administrativa, embora os deveres possam ser partilhados com parentes. Na tribo, similarmente, o cacique assume responsabilidade, porém é mais provável que ele partilhe os deveres com amigos de confiança assim como com a familia. As sociedades crescem e seus arranjos aumentam de complexidade. De modo que a função administrativa se torna cada vez mais diferenciada de outras funções e os deveres são assumidos por instituições especializadas e agentes profissionais. Até mesmo em sociedades altamente complexas, porém, a responsabilidade pela função administrativa ainda está integrada com a responsabilidade pelo exercicio de outras funções na sociedade e repousada na elite social. Similarmente, nem todos os deveres administrativos têm sido (ou poderiam ser) assumidos por instituiç̃es especializadas e agentes profissionais. Conseqüentemente, a função administrativa é muito mais ampla do que as instituições especificamente administrativas e as posições administrativas de tempo integral. É este, certamente, o caso nas sociedades que se encontram em nivel de desenvolvimento relativamente baixo e onde o povo não tenha concebido um vocabulário administrativo em sua linguagem do dia-a-dia ou onde o mesmo termo para o conceito de administracão possa também significar direção, supervisảo, ordem, autoridade, funcionalismo simplesmente porque não haveria necessidade de conceber uma linguagem mais sofisticada para fins administrativos. $\mathrm{Pa}$ ra fins de desenvolvimento, a identificação da administração com as formas mais altas de profissionalização administrativa e especializacão é indevidamente restritiva. Na identificação da capacidade admínistrativa, talvez tenhamos de nos apoiar em termos mais simples e mais gerais, usando a palavra "administrador" para abranger quem quer cujos deveres principais contenham alto teor administrativo, inde- pendentemente da posição (ou posiçóes) que a pessoa ocupe e do título dado a tal posição (ou tais posiçoes), em vez de a identificarmos com posições de alto nivel em estruturas burocráticas.

Um significado mais integrativo da função administrativa seria relacionar imediatamente a capacidade administrativa com os complexos arranjos em que ela está enredada na sociedade. Está intimamente ligado com a capacidade da sociedade de adaptar-se a novas condições e adotar padrões de ação diferentes, coexistir com problemas e viver com diversidade e variedade, estender 0 sobejo da sociedade de acordo com a complexidade e inovar não somente em tecnologia como também em arranjos na sociedade. E prejudicado por elementos sociais que resistem à mudança, isto é, pelo grau em que as sociedades são inerentemente

\begin{tabular}{|c|}
\hline A função \\
administrativa \\
é muito mais ampla \\
que as instituiçoes. \\
As sociedades \\
crescem e seus \\
aparatos funcionais \\
se tornam mais \\
complexos. É \\
preciso usar termos \\
mais simples e \\
mais gerais na \\
burocracia \\
de todos os niveis.
\end{tabular}

conservadoras, preferindo o bem provado a arriscar-se a inovaçōes, satisfeitas com o status quo e a respeito do futuro. Se a luta para alcançar as presentes realizaçoes é exaustiva, é provável que poucas pessoas optem pela rotina enfadonha da mudança perpétua. Se as elites temem que sua posição venha a ser minada ou impugnada, talvez resistam à mudança. Similarmente, se as massas não vêem vantagens para elas próprias na mudança, talvez não façam esforço por mudança e, se estão dispostas a mudar o que fazem, talvez não estejam tão dispostas a mudar a maneira como o fazem. Quando as coisas parecem estar indo bem, ninguém se preocupa demasiadamente em saber se elas poderiam ser melhoradas com o aumento da capacidade administrativa. Quando as coisas vão mal, todos se preocupam demasiadamente com questões substantivas para lidar com arranjos administrativos. As matérias administrativas tendem, portanto, a padecer de negligência e a mudança nos sistemas administrativos, provavelmente, ocorrem a um ritmo mais lento em comparação com outras funções. Se as mudanças previstas são consideradas excessivamente radicais, são rejeitadas de plano ou adotadas de maneira a reduzir ao minimo ou destruir seu efeito. Assim, uma sociedade madura para o desenvolvimento achará dificil uma mudança acelerada (embora cada vez mais fácil no tempo à medida que o ritmo se apressa) e mais dura ainda uma reforma administrativa.

$\mathrm{Na}$ busca de meios para superar o conservantismo da sociedade a fim de atingirem o ponto de desenvolvimento auto-sustentado, os paises pobresão grandemente influenciados pelós modelos de desenvolvimento preferidos no momento. No presente, inclinam-se para a capacidade reveladora de desenvolvimerito da natureza, isto é, para a incessante evoluça para coisas mais altas, governadas pelas leis científicas do crescimento e da transformação que podem ser descobertas pelo homem e, portanto, são capazes de ser dominadas e talvez manipuladas pelo desenvolvimento acelerado. De acordo com esta visão, a reforma administrativa, juntamente com o planejamento do desenvolvimento e a aceleração da mudança social, é unia parte legítima da engenharia de sistemas. Mas isto ainda não soluciona o problema sobre o que mudar e de que forma aumentar a capacidade administrativa. Para este fim os modelos das duas maiores superpotências, modificados por variações na experiência de seus associados mais importantes em seus respectivos campos ideológicos, são fortemente influentes. $O$ modelo ocidental presume uma ética protestante de trabalho árduo, obediência à autoridade, austeridade e liberalidade. Numa sociedade livre, interesses diferentes competem pelo poder, por posições, por status e por re- 
compensas e é esta competição que aciona o engenho inventivo, liberta as massas da ignorância, da imobi lidade e da servidão e impede o monopólio de um só grupo. Para reduzirem a incerteza e a insegurança, os interesses em competição concebem regras do jogo consensuais que impedem a liquidação involuntária, respeitam as reivindicações dos desprivilegiados, mas dão a parte do leão aos privilegiados. $O$ desenvolvimento é o resultado cambiante da luta que nảo pode ser predeterminado nem conscientemente controlado. Com o correr do tempo, a luta se torna intricada, o resultado cada vez mais complexo, as ligaçoes mais complicadas, a sociedade mais especializada e interdependente, as ações mútuas na socierade intensificadas, à produtividide expandida. A função administrativa é manter uma competição honesta, apoiar o engenho inventivo, conservar as regras do jogo e organizar as açōes mútuas, cada vez mais complicadas. No caso de as potencialidades da iniciativa privada falharem de algum modo, a iniciativa pública intervém. Se não se gera naturalmente suficiente capacidade administrativa em resposta a necessidades, então a iniciativa pública intervém para impulsionar a iniciativa privada, eliminar obstáculos técnicos (como, por exemplo, o analfabetismo, a falta do incentivos, tecnologia de baixo nivel) e substituir a ação pública. Os elementos essenciais neste modelo são instituições políticas democráticas estáveis, segurança interna, propriedade privada, incentivos materiais, mobilidade social, regulamentação econômica keynesiana č uma filosofia de bem-estar.

O modelo oriental também pressupõe uma nova visåo social que rompe a tirania do tradicionalismo, uma visảo bascada nåo na iniciativa individual, na competição mútua e no investimento governamental destinado a induzir uma expansão auto-sustentada da atividade econômica, mas no coletivismo, no desenvolvimento planejado e no predomínio da iniciativa particular. Como nenhuma elite renuncia voluntariamente a sua posiça e a sua capacidade de manipular a competicão particular e a intervenção pública em favor do status quo lou do crescimento com uma mudança

\section{IDÉIAS}

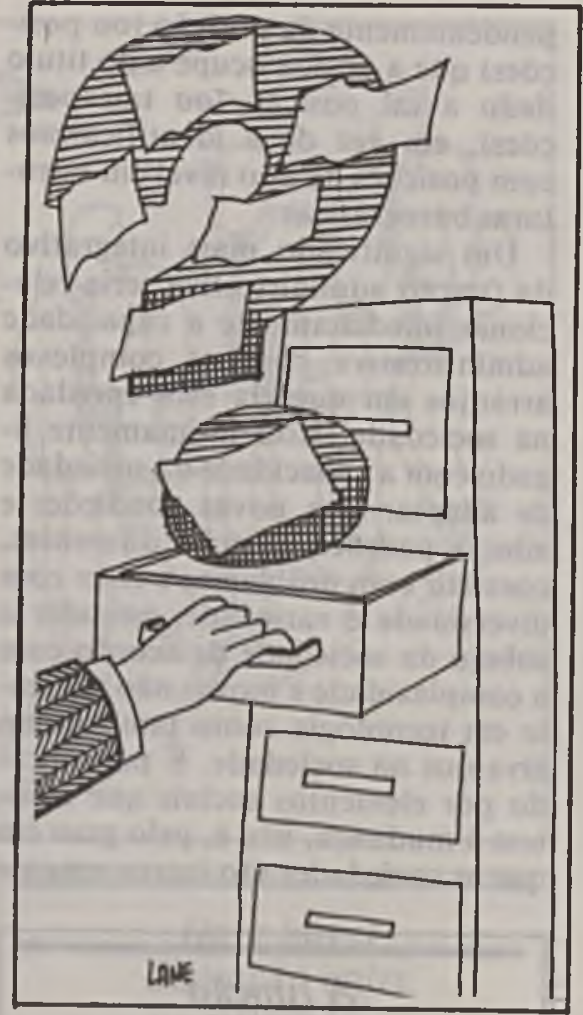

mínima de sistema), a mudança na sociedade não pode ocorrer pacificamente ou ser revolucionária. O poder, as instituiçoes e os valores das clites tradicionais precisam ser destruidos através de uma revolução organizada por determinados coletivistas proletários, não por empreendedores capitalistas burgueses de classe média. Os revolucionários lliko somente erradicariam a supersliçĭo, o dominio religioso da educacilo c o aumento do sistema familiar como também eliminariam o poder das elites tradicionais, expropria-

Uma renovação
completa é impossivel
e impraticável. Muita
coisa tem de ficar.
Precisa existir certo
grau de aceitação
voluntária. Em muitos
casos, as resistências
começm quando a ação
vai sair da teoria
para a prátiça. Ai
despontam as reais
reações contra as
mudanças na estrutura.

riam a propriedade particular através da propriedade pública e da coletivização, substituiriam a livre competição por um planejamento centralizado e a "livre" escolha por controles e incentivos administrativos e trabalhariam no sentido de uma igualdade social e de um entusiasmo em massa pelo desenvolvimento. A função administrativa é organizar o planejamento centralizado, apoiar o empreendimento coletivista, manipular incentivos e controles de acordo com as metas de desenvolvimento e organizar a crescente complexidade da interação social. Se deixa de materializar-se suficiente capacidade administrativa derivada do planejamento do desenvolvimento, então a iniciativa públiça revê esquemas e organogramas, elimina obstáculos técnicos e corrige as deficiências do empreendimento público. Os elementos essenciais neste modelo são instituições politicas participátivas estáveis, segurança interna, propriedade públi$\mathrm{ca}$, incentivos sociais, planejamento econômico central, coletivização e uma ideologia proletária.

Sem subestimar a ampla diferença de abordagem do desenvolvimento existente entre estes dois modelos, administrativamente há notáveis similaridades, até mesmo à parte considerações econômicas táticas de "altas taxas de formação de capital; prioridade de indústrias básicas de bens de capital; inclinação a favor de tecnologias modernas, de uso intensivo de capital e processos fundamentais combinadas com técnicas de uso intensivo de māo-de-obra em operaçoes auxiliares; uma política de substituição de importações no comércio internacional; utilização de mão-de-obra agrícola subempregada para a formação de capital; e forte investimento em capital humano (9)". Ambos aspiram ostensivamente aos mesmos fins - o minimo de insegurança, de injustiça, de desigualdade, de pobreza, de estagnacão. Ambos partilham uma ética, padrōes, ciência e tecnologia de origem européia. Ambos presumem a universidade de seus respectivos modelos. Ambos são essencialmente materialistas e racionais. Ambos acentuam a capacidade administrativa através do "burocratismo", de normas juridico-racionais, da organização e mecanizaçảo em grande 


\section{IDÉIAS}

escala. Os administradores se sentiriam em casa em qualquer dos dois modelos, mais em casa se fossem lançados em sociedades prismáticas e tradicionais. Naturalmente, não se movimentariam facilmente entre economias planejadas e competitivas, instituiçōes privadas e coletivistas, mercados de trabalho livres e não livres, elaboração de politica pública não ideológica e ideológica e ambientes autoritários e liberais, mas padeceriam menos de choque cultural, incerteza, escassez, ambigüidade, indefiniçăo e pura incompatibilidade, incompreensão e ignorância.

Os paises não alinhados que aspiram a desenvolvimento acham que ambos os modelos subestimam certos aspectos. Ambos os caminhos, historicamente, têm sido tortuosos, nada suaves como está implícito nos modelos, marcados por considerável violência, ruptura, miséria e exploração. Grupos inteiros foram sacrificados. Foi usada coerção física contra os discordantes. As massas foram manipuladas, enganadas e abandonadas. Os custos foram pesados, embora ambos exportassem parte do dispêndio para outros países de dentro de suas esferas de influência mas os custos seriam outra coisa que não a continuação do tradicionalismo, nos dois casos? Nenhum dos dois modelos revela o papel do militarismo no crescimento do capital e no estimulo econômico. A vitória na guerra trazia acesso a novos recursos e novos mercados. A derrota. levava a um auto-exame crítico e à reconstrução. A rivalidade militar estimulava a pesquisa e desenvolvimento em nova tecnologia. Os gastos com defesa eram usados para obras públicas de desenvolvimento. As estruțuras militares tornavam-se a base das organizaç̃es civis e a educação e o treinamento administrativos eram, inicialmente, moldados segundo técnicas militares (mas onde haverá substitutos pacíficos?). Nenhum dos dois modelos lida adequadamente com as verdadeiras variaçōes e os verdadeiros afastamentos ou bolsões de tradicão deixados para trás. Apesar disto, os paises pobres impressionam-se e gostariam de tomar emprestado o que pudessem para ajustá-lo a suas próprias circunstâncias, que eles compreendem que são diferentes daquelas das grandes potências antes da decolagem para o desenvolvimento rápido. Mas eles querem seu próprio tipo de desenvolvimento, de acordo com suas aspiraçōes nacionais e sua ideologia neutralista. Esperam preservar seus padrões culturais nacionais sem abraçar plenamente a ocidentalização, o capitalismo monopolista ou o totalitarismo. Procuram outros rumos para o desenvolvimento e querem conceber alternativas sem cairem na armadilha de estados clientes neo-colonialistas. Buscam uma engenharia de sistemas aplica-

\begin{tabular}{|c|}
\hline O modelo oriental \\
pressupõe uma nova \\
visão social que \\
rompe com a tirania \\
do tradicionalismo \\
e se baseia no \\
coletivismo e \\
no planejamento \\
auto-sustentado da \\
atividade econômica. \\
Mas nenhuma elite \\
renuncia de maneira \\
volutária aos \\
seus privilégios.
\end{tabular}

dos para acelerarem os processos de desenvolvimento, ajuda e assistência internacionais maciças, o florescer do talento nacional com a eliminação do poder estrangeiro, modernização organizada por órgãos públicos, desenvolvimento econômico e político dirigido e administração pública revitalizada. Em comparação com o Oriente e o Ocidente, deve ser colocada menor ênfase na iniciativa privada ou num partido revolucionário e maior ênfase em estruturas públicas burocráticas. O desenvolvimento dirigido toma um rumo entre o comunismo e o capitalismo, a afluência e o colapso, a uniformidade e o fracionamento, a licença e a escravidão. Deve ser um desenvolvimento cuidadoso.

$O$ desenvolvimento cuidadoso necessita de um apoio administrativo efetivo e de uma capacidade administrativa correspondente, particularmente no setor público. Nenhum modelo novo de desenvolvimento pode ser aplicado sem considerável preparaçao e precondicionamento. Os instrumentos nāo aparecem da noite para o dia por mágica. Muitos paises pobres carecem de potencialidade assim como de recursos reais e não têm acesso a novas fontes, exceto capital humano, que ainda é um material fraco. O talento criativo vai-se embora, seduzido por melhores recompensas em outros lugares ou exasperado por um ambiente hostil. A tecnologia nova tem de ser importada. As instituições de origem estrangeira e a ajuda internacional mostram-se apenas muletas temporárias, causando dano ao crescimento nacional e colocando uma camisa-de-força na ação local justamente quando há necessidade de flexibilidade, adaptabilidade e criatividade. Os arranjos políticos não refletem uma redução da instabilidade, insegurança e crise do ambiente. A capacidade administrativa já é um recurso escasso nos paises pobres. Como deverá ser ampliado em tais condições?

A Organização das Nações Unidas acredita que o aumento da capacidade administrativa depende do fortalecimento dos sistemas de administração pública para apoiar o papel expansionista do Governo no desenvolvimento.

A capacidade das organizaçð̄es governamentais de identificar e definir problemas, determinar politicas e programas de desenvolvimento, atribuir prioridades entre reivindicaçōes em competição, distribuir recursos, desenvolver habilitaçōes necessárias, usar a ciência e a tecnologia para o desenvolvimento e executar programas de ação será úm fator decisivo no resultado dos esforços nacionais pelo desenvolvimento. $\dot{A}$ medida que os problemas econômicos e sociais se tornam mais complexos, o papel central da administração pública se torna mais fundamental (10).

Esta atitude realista baseia-se no fato de que os paises pobres têm de trabalhar com a situaça em que se encontram. Não podem desejar afastá-la. Precisam resistir à transferência e olhar para dentro. Ainda carecem de conhecimentos elementares sobre eles mesmos. Assim, não podem identificar adequadamente recursos para o desenvolvimento ou 


\section{IDÉIAS}

formular programas de desenvolvimento práticos, viáveis e aceitáveis. O conservantismo administrativo tradicional é reforçado por turbulência na soçiedade, instabilidade politica, limitações de recursos e choques a respeito de valores e prioridades na modernização administrativa. Apoiar-se na evolução natural talvez seja suicídio. $O$ aumento da capacidade administrativa só pode ser desenvolvido partindo de dentro, como um subproduto do próprio desenvolvimento, ou através de uma experiência governamental deliberadamente continua.

\section{A SITUAÇÃO DOS PAISES PO- BRES}

De um modo geri os países pobres concordam com a estratégia da Organização das Nações Unidas de fortalecimento da administração do setor público e do uso do Governo como a ponta de lança do desenvolvimento dirigido. Encontram-se num mundo bipolarizado - senão tripolarizado - não feito por eles e; enquanto as grandes potências competem para atrai-los para as respectivas esferas de influência, podem extrair um preço de cada uma delas como um sinal de cordialidade e neutralidade - preço talvez superior àquele que poderia ser obtido através do alinhamento. Vários paises pobres têm alcançado muito êxito, em termos de ajuda e assistència, com sua atitude equilibrada. Ao se iniciarem os anos 70, as grandes potêrcias já haviam começado a cansar-se das acrobacias e a reduzir seus compromissos ou a canaliza-los atraves de órgăos internacionais. De qualquer modo, o volume total da ajuda internacional aos paises pobres sempre foi marginal para suas necessidades $\mathrm{c}$ mais do que neutralizado pelos adversos termos de comércio internacional. $\mathrm{O}$ principal esforço tem de vir de dentro. Enıbora a ajuda de fora seja valiosa, o autodesenvolvimento é melhor em termos de independência, auto-apoio, confiança e aprendizado de experiência. Contudo, a movimentação para'o autodesenvolvimento através de agentes nacionais não deixa de considerar a assistência externa nem as pressões e influências internacio. nais. A revolução de elevaça de expectativas, por exemplo, está levan-

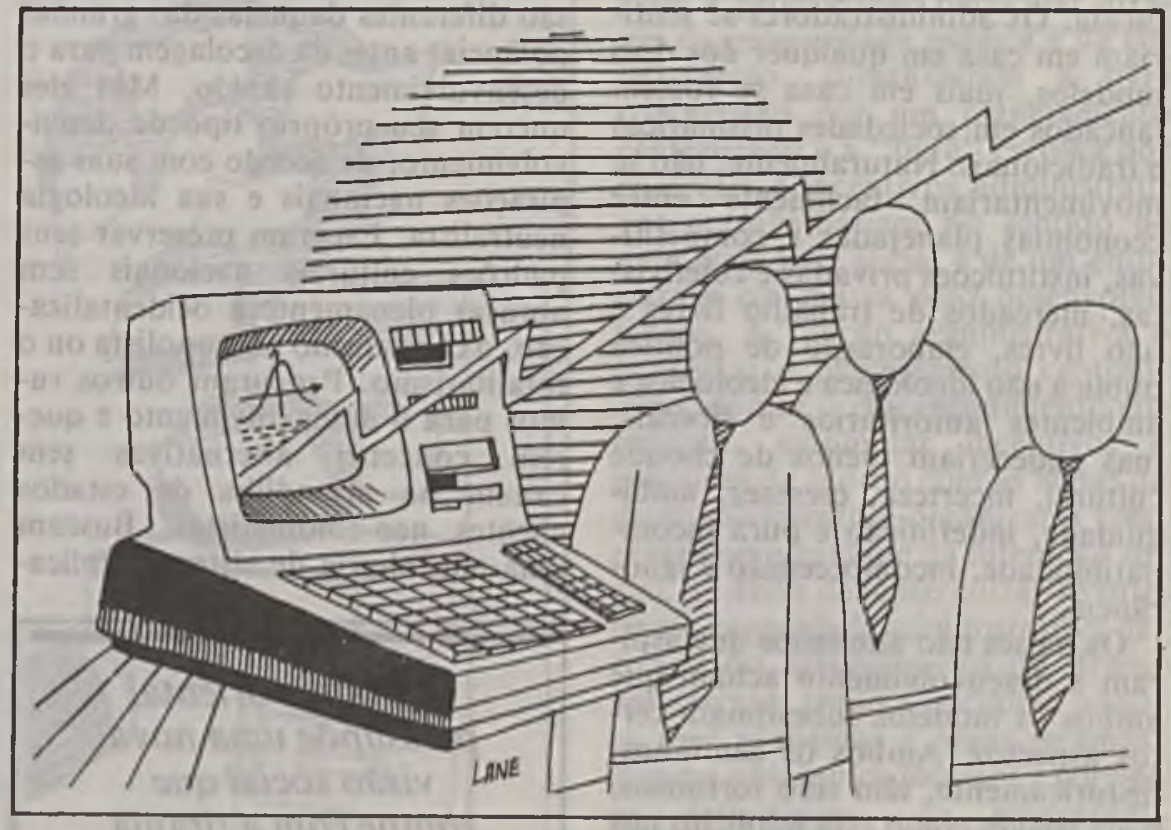

do estados a modernizar-se e criando um clima favorável para uma mudança radical. Estas tendências fortalecem a iniciativa governamental no processo de desenvolvimento e na modernização da administração pública.

A administração já está sobrecarregada cm muitos países pobres.

\begin{tabular}{|c|}
\hline Odesenvolvimento \\
necessita de apoio \\
administrativo e da \\
correspondente \\
capacidade, no setor \\
público. Nenhum modelo \\
novo pode ser aplicado \\
sem considerável \\
preparação e \\
precondicionamento. \\
Mas os instrumentos \\
não aparecem da noite \\
para o dia nem por \\
mágica ou milagre.
\end{tabular}

Tantas tarefas novas têm sido acumuladas em administraçōes insuficientemente preparadas que elas estão próximas do ponto de rompimento. Crises pegam-nas despreparadas. Exércitos fracassam em combate. Epidemias grassam sem controle. Leis são abertamente violadas. A ordern aparente nas sedes é conseguida, geralmente, a expensas do caos no trabalho de campo. O trabalho de campo frouxo carece de quaisquer recursos para a ação, porque as sedes não têm recursos para destinar-lhe ou porque em algum ponto existe um ponto de estrangulamento. Para os administradores com empenho, a vida é uma luta longa e árdua sem descanso e o esgotamento reforça a inércia burocrática e o conservantismo administrativo que caracterizam a administração pública em muitos países pobres. Quanto maior a pressão por mudança, mais a administração é impelida na direção do colapso, mais resistentes são os administradores à inovação e mais imperativo é um empenho governamental forte em reformas radicais para gerar o aumento da capacidade administrativa a fim de atender às pressões por mudança. Até que se crie uma capacidade adicional, a diferença entre intençãn e realização deve crescer, apenas alimentando frustração, confusão, decepção e descontentamento.

Dos três principais modos de aumento da capacidade administrativa - através da inovação, do subproduto do desenvolvimento e da reforma - os países pobres têm pouca alternativa para a reforma. A inovação administrativa é rara. Sua ocorrência é tanto por acaso como a esmo. Os paises ricos estão melhor colocados para alimentar o talento criativo, investir em pesquisa e desenvolvimento, experimentar mode- 


\section{IDÉIAS}

los operacionais e mudar de modos de operação. Os paises pobres costumam ser imitadores: tomam emprestado ou copiam em vez de inventar. Também padecem de complexo de inferioridade em materias administrativas, acreditando que os meios adotados pelos paises ricos são superiores. São excessivamente modestos a respeito de suas próprias inovaçðes e do talento nacional. Toda a questão do aumento da capacidade administrativa está em ampliar o desenvolvimento, não na maneira oposta. Mesmo assim, o aumento como um subproduto do desenvolvimento é relativamente lento $\mathrm{e}$ incerto. Não há garantia de que niveis mais altos de instrução, saúde, tecnologia, unidade, investimento, liberdade, etc. se refletirão em melhoria do desempenho administrativo. Arranjos antiquados talvez persistam muito tempo depois de terem servido a seus fins e de surgirem melhores alternativas. Mesmo se fluirem beneficios para a cultura administrativa, talvez ocorra um atraso de uma geração - e o tempo não está do lado dos países pobres. Assim, do mesmo modo como eles detalham objetivos políticos, planejam o crescimento econômico e trabalham para transformar as condições sociais, necessitam conceber programas de modernização administrativa para a melhoria sistemática do desempenho administrativo ou, para usar uma expressão mais curta, da reforma administrativa.

A maioria dos paises - ricos e pobres - embarcou ou planeja embarcar numa reforma administrativa. Uns foram forjados a movimentar-se por pressão interna:ional, como um prelúdio para ajuda ou para cooperação regional. Outros incorporaram a reforma administrativa a suas vastas transforma çỏes do colonialismo para um stalus independente ou do capitalismo para o socialismo. Uns temem que o desempenho rotineiro contínuo talvez leve suas administraçōes a uma parada e elas entrem subitamente em colapso. Outros vêem seus programas de reforma administrativa como parte de sua guerra à pobreza ou de sua luta contra o subdesenvolvimento - que é a visão adotada pelos órgãos das $\mathrm{Na}$ çōes Unidas na América Latina e na Asia. Uns querem passar de iniciais preocupaçōes nacionalistas para uma administração de fins múltiplos acionada para obter resultados mais efetivos (isto é, visiveis, concretos e rápidos), um desempenho eficiente e econômico e integração social (11). Outros meramente querem uma revisão episódica de sistemas administrativos antiquados, num exame geral de seu mecanismo de governo e das instituiçðes associadas. Uns meramente querem aplicar as recomendaçōes de comissōes de reforma formadas em paises ricos (12). Outros querem "algo mais do que a aplicaç̃o técnica de princípios administrativos e a adoção ou adaptação de experiências positivas de outros paises mais avançados", isto é, uma estratégia que inclua "formas diversas de organizaça políticoadministrativa no estado, assim como a superação das forças opostas à modernização da administração pública" (13). Muitos paises pobres institucionalizaram seus programas de reforma dentro da estrutura governamental como um processo continuo para variar as estrategias de reforma com circunstâncias cambiantes, coordenar o aumento da capacidade administrativa com outros

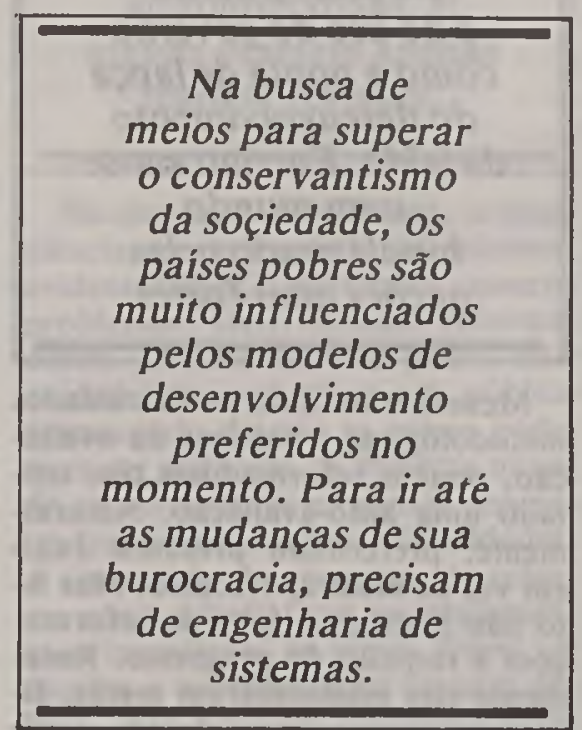

processos de desenvolvimento, incorporar uma unidade de renovaçao administrativa e desenvolvimento ao mecanismo de governo e abrir a possibilidade de um avanço administrativo significativo.

A maioria dos programas de reforma partilha uma abordagem comum. Tais programas projetam conceitos de origem européia sobre tempo, trabalho, contrato, economia, conhecimentos, e realizações, incentivos materiais, autoafirmação e participação que se tornaram universais na civilização industrial. Alguns deles contrastam acentuadamente com os valores locais. Vão de tal modo de encontro aos valores predominantes que nem mesmo seus defensores os seguem, apesar de louvarem amplamente o contrário e criticarem as práticas locais. Esta ênfase na infra-estrutura cultural é importante, mas costuma glorificar excessivamente conceitos estrangeiros sem minucioso conhecimento das verdadeiras práticas das civilizações industriais e denegrir as práticas locais de uma maneira excessivamente generalizada. As normas estrangeiras são tidas como ideais. Os reformadores copiam servilmente práticas estrangeiras ou referem-se aos últimos textos estrangeiros como sua bíblia sobre o que fazer o que n-ao fazer. Se a verdade fosse conhecida, então se saberia que os paises ricos e pobres estão muito mais perto uns dos outros administrativamente do que suspeitam. As civilizaçōes industriais não são tão eficientes quanto proclamam. Em face da diferença de fases de desenvolvimento, da variação das circunstâncias e do contraste dos objetivos, os paises pobres têm pouca razão para se sentirem inferiores administrativamente.

Imitando práticas estrangeiras, os paises pobres deslizam para uma concepção mais estreita de administração do que precisariam. Seus programas básicos centralizam-se nos àspectos de economia doméstica de organizações de grande porte. A estes fóram acrescentados tomada de decisões, ciências de administração, planejamento nacional e a busca de indicadores sociais, atividades que ampliam as concepçōes da funcão administrativa. Além disto, porém, há mais concentração nos aspectos administrativos de projetos e programas setoriais e de questỏes de desenvolyimento como produtividade, moralidade pública, desenvolvimento comunitário e solvência financeira. $\mathrm{O}$ grande inconveniente é o evidente desinteresse pelas conseqüências não administrativas do desenvolvimento administrativo, como a mudança da estrutura social através do recrutamento aberto e da 


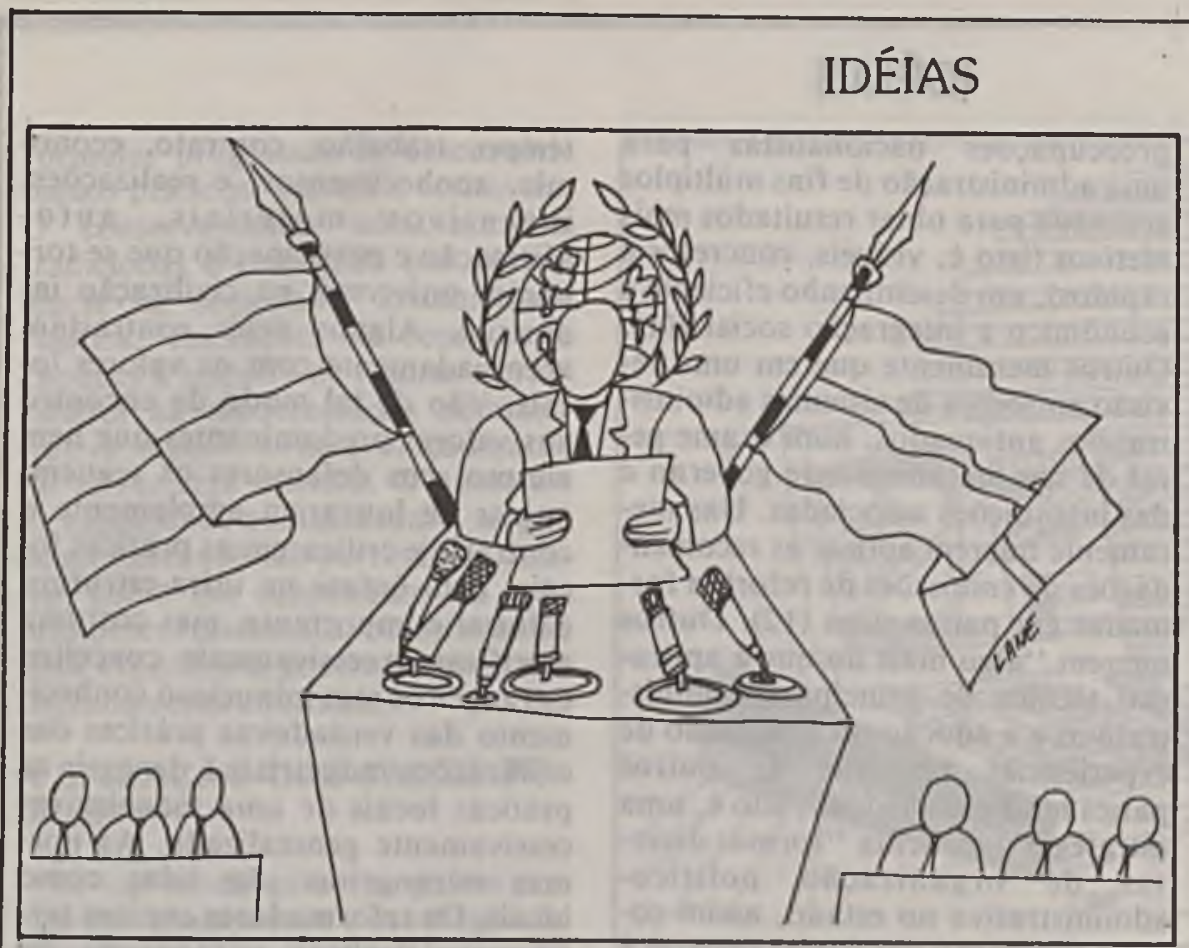

classificação dós empregos, ou a excessiva poluição derivada do aumento da produção ou os programas de congelamento para a desaceleração da inflação. Em certo grau, a concepção estreita reflete o desejo dos reformadores de permanecerem fora do conflito político marginal ou partidário e de acentuarem sua proficiência profissional e técnica, o que não poderiam fazer se encarassem a administração de modo mais amplo e se envolvessem em mudancas sociais fundamentais. Como resultado, constumam ser relativamente conservadores, reativos, cm vez de ativos. Reagem a deficiências observadas te admitidas. Raramente as prevêem. Seu objetivo sto a manutenção e correação de sistcmas $\mathrm{cm}$ vez da substituiçđo de sistemas. Suas reformas sio, cm essência, legitimas, incrementadoras, ortodoxas, e estabilizadoras. Isto dificilmente seria de surpreender, pois os reformadores institucionais são recrutados, predominantemente, cm elites firmadas e săo identificados como o próprio sistema que devem reformar. Muitos estudaram no estrangeiro e têm inclinação acadêmica em vez de politiça. Sabedores da extensão da resistência, têm de firmar-se. Conseqüentemente, como técnicos. proficientes, remendando sistemas antiquados, talvez acabem causando mais danos do que bem, particularmente na resistência a inovações fora de suas estreitas concepções de administração. capazes de manter qualquer espécie de administração por força de seu status colonial, de seu pequeno tamanho ou de sua extrema pobreza quanto se considerarmos paises capazes de alcançar altos niveis de inovação administrativa, revitalização e auto-renovação. Tais reformadores deixaram de obter adequado apoio de lideranças para superar a displicência politica, a inércia burocrática, a apatia pública e a resistência sistemática não meramente por força da preocupação da elite com matérias de maior prioridade ou por força da falta de atração visual (ou social politica) de uma reforma administrativa tangivel. Visionários, publicistas e reis filósofos administrativos figuraram bastante entre eles, enquanto órgãos de reforma tiveram mais do que seu quinhão justo de exilados políticos, párias administrativos, executivos esgotados, caturras, notáveis incompetentes e extenuados. Conseqüentemente, os programas de reforma, carecendo de autoridade, de recursos e de insistência, foram isolados, desprezados e deixados de lado. Felizmente, as exceçōes à regra geral mantiveram viva a confiança na eficácia fundamental dos esforços de reforma administrativa e a continuarem $o$ investimento em programas de reforma por parte de órgãos internacionais e nacionais.

Claramente, os paises pobres aprenderam, a algum custo, que não existe uma fórmula universal de êxito na reforma administrativa. Como as premissas iniciais permanecem válidas - de que a reforma administrativa tem de ser preferida a seus parceiros, à inovação administrativa e aos subprodutos do desenvolvimento, de que a administração é algo mais do que economia doméstica organizacional, de que os modelos estrangeiros ligados à cultúra não são inevitavelmente transferiveis, adequados ou apropriados, de que os reformadores precisam praticar o que pregam -, cada país precisa moldar seus programas de acordo com suas circunstâncias singulares, entre as quais eståo, principalmente, sua fase de desenvolvimento, seus padroes culturais, seu regime politi$\mathrm{co}$, seu açesso ao talento administrativo e seus requisitos funcionais. Embora a reforma administrativa seja, basicamente, uma forma de ar- 


\section{IDÉIAS}

te, hâ alguns elementos universais que não podem ser esquecidos. Primeiro: a reforma administrativa é um componente de baixa prioridade no processo do desenvolvimento. Onde faltam outros componentes, a administração torna-se, convenientemente, o bode expiatório dos fracassos no desenvolvimento. Segundo: se os reformadores encararem sua própria contribuição em termos formais estreitos, continuarão a ser rebaixados e sacrificados a objetivos mais importantes da sociedade. Sua posição marginal empalidece diante da tarefa maior de determinar como uma sociedade quer conduzir seus assuntos, que é inseparável do debate geral a respeito da natureza da sociedade e do significado do desenvolvimento. Terceiro: o alcance e as fronteiras dos programas de reforma excluem, em grande parte, institucionalmente, os empreendimentos privados, as associações de voluntários e a administração rural e, estruturalmente, os fundos públicos autônomos, a fuga aos impostos e sua evasão, a corrupção, a extravagância e os projetos de prestígio, isto é, entre escândalos e tragédias. Dificilmente se terá compreendido até agora a potencialidade do progresso da reforma administrativa. Quarto: o isolamento dos programas de reforma administrativa em relação à politica pública, ao planejamento nacional e aos programas de reforma funcional tem diminuido seu impacto. A integração melhora as coisas desde que as reformas fossem planejadas em ciclos superpostos, de certa forma sistemática, para reduzir as brechas no tempo e na área, os acompanhamentos ao acaso e a necessidade de repetir trabalho anterior. Quinto: a introdução casual de programas de reforma dependentes de escândalos, golpes políticos, mudanças de liderança e outras ocorrências eventuais quando a tolerância da má administração é tentada com muita freqüência acarretaria menos improvisação se fossem aprontados planos contingenciais para introdução no planejamento ou nos ciclos orçamentários em vez de se esperar por melhores circunstâncias que talvez nunca chegassem. Para os reformadores ligados a idéias fixas, época alguma está madura para reforma. Finalmente, os reformadores se dividem a respeito da questão da dramatização entre os divulgadores, que querem o máximo de cobertura dos meios de comunicação empenho público, simbolismo e comemoração de uma nova ordem e aqueles que se escondem, preocupados em não provocar resistência indevida, oponentes prevenidos e colocar-se numa posição sem compromisso. Os últimos prefeririam uma demonstração impressionante de resultados numa experiência piloto a uma campanha pública ruidosa com nada para apresentar exceto um pensamento ansioso e esperancas otimistas.

\begin{tabular}{c}
\hline Os países ricos \\
têm maiores chances \\
de reestruturar \\
suas administraçōes \\
porque podem \\
investir em pesquisa \\
e apoiar a criatividade \\
de seus talentos. Mas \\
a maioria dos povos \\
ou já fez ou pensa em \\
fazer reformas \\
administrativas. E \\
alguns desejam apenas \\
realizar revisōes.
\end{tabular}

No processo de reforma, a consciência da necessidade de reforma, evidentemente, apresenta poucos problemas. Determinados reformadores, geralmente, têm pouca dificuldade em convencer um público preocupado de que as coisas poderiam ser melhores. E somente quando se apresentam propostas concretas que começam suas dificuldades. A concepção de propostas de reforma não é difícil. Com encorajamento e incentivos, as idéias fluem. A escolha e a organização causam debate, mas nenhum problema sério até que tenha de ser feito algo. Suas propostas têm de ser consideradas efetivas e o que é efetivo depende menos das próprias propostas do que das pessoas - os reformadores e os potencialmente reformados que as julgam. A avaliação pósreforma apresenta, realmente, sérias dificuldades, mas, como, em geral, esta fase é omitida ou cumprida su- perficialmente, a execução é que é o verdadeiro obstáculo.

\section{O PROCESSO DA EXECUÇÃO DA REFORMA}

A maioria dos movimentos de reforma, dos reformadores e das reformas tropeça no conservantismo administrativo, causando pouca impressão. Algumas linhas mestras emergem de um exame dos êxitos e fracassos de reformas.

\section{A. CONHECIMENTO DA SI- TUAÇÃO DA REFORMA}

$\mathrm{Na}$ reforma administrativa, é virtualmente fatal empenhar-se em alguma coisa âs cegas, exceto quando a situação é realmente desesperadora, como quando uma reação administrativa leva a uma rápida obsolescência em que nada senāo um novo começo ajudaria numa situação intolerável. Mais tipicamente, a reforma é introduzida em situações em que existe dúvida quanto ao que deve ser feito para melhorar o desempenho. Uma renovação completa é impossivel e impraticável. Seja o que for que aconteça, grande parte do que já existe permanecerá. Como não pode ser exercida coerção o tempo inteiro, precisa existir certo grau de aceitação voluntária. Para se conseguir a cooperação necessária, os reformados em potencial precisam ser convencidos de que as reformas sāo viáveis e práticas e constituirão, realmente, uma melhoria em relação aos arranjos existentes. Tudo isto implica um conhecimento completo, da parte dos reformadores, daquilo que eles devem fazer.

Comó é provável que nunca os reformadores tenham informações suficientes, é necessária certa seletividade. No minimo, eles têm de conhecer os fatos básicos a respeito da situação da reforma, os prós e contras de suas próprias propostas, o alinhamento provável e certa variedade de estratégias possiveis. Além disto, seria desejável ter uma compreensão histórica da situação, certo conhecimento de tentativas anteriores de reforma, avaliaçðes da personalidade de gente influente no processo de reforma e dados adequados sobre $n$ andamento. Grande parte destes conhecimentos é especifica da situação e só pode ser obtida em pri- 


\section{IDÉIAS}

meira mão. Uma parte pode ser coIhida em registros acumulados, estudos específicos e literatura geral, mas este material costuma acentuar afirmações e documentação anedóticas cronológicas, prescrições dogmaticamente normativas, vulgaridades ingenuamente abstratas, metas e esquemas utópicos ou asserções hipoteticamente lógicas concluidas por raciocinio dedutivo, freqüentemente na base de premissas estabelecidas inadequadamente... Muitas das idéias apresentadas... permanecem como sugestões inertes... sendo, na maioria dos casos, criação de um pensamento sincero, mas, infelizmente, calcado no desejo em vez de ser realista... O que é realmente necessário são uma rigorosa pesquisa empirica e um desenvolvimento conceitual criativo para distinguir entre: (a) a maneira complexa e às vezes aparentemente confusa com que as coisas acontecem na verdade; (b) a maneira com que os teóricos pensam que as coisas devem acontecer; e (c) a maneira com que as coisas podem ser feitas, realisticamente, na base de nova dissecação e de remontagem dos acontecimentos (14).

\section{B. DIAGNÓSTICO CORRETO}

Sem os fatos, não é possivel qualquer diagnóstico e, mesmo com os fatos, o diagnóstico pode ser incorreto por força de interprelaçóes falhas. Um diagnóstico incorreto pode matar as perspectivas de reforma logo de saida. Mas, como, em geral, as situaçōes administrativas sio complicadas e os reformadores suficientemente competentes, um diagnóstico errado nunca é muito claro. Somente na execuça as dúvidas se confirmam. Infelizmente, a execução de reformas para corrigir falhas diagnosticadas erradamente piora a situação: o tratamento incorreto talvez seja pior do que fazer nada. $O$ diagnóstico correto depende também de experiência e raciocínio. Os administradores acostumados a atuar em situaçóes diferentes desenvolvem um faro para falhas e aprendem a detectar sintomas. Os especialistas administrativos aplicam técnicas científicas e talvez um discernimento natural do diagnóstico. Mas ninguém não produziu um manual de consultas para reformadores em perspectiva.

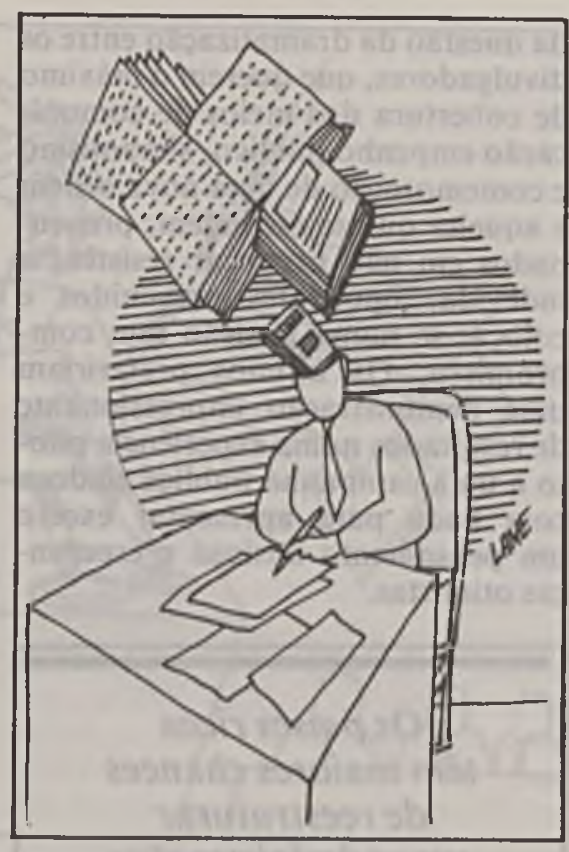

Uma lista derivada de uma consideração teórica de sistemas administrativos sugere que ocorrem falhas importantes porque uma administração procura fazer coisas que não pode fazer (objetivos inatingiveis) ou porque os arranjos administrativos não permitem que os administradores façam o que têm de fazer (estrutura obstrutiva) ou porque algum componente não está cumprindo a tarefa que é esperada dele (desempenho inadequado).

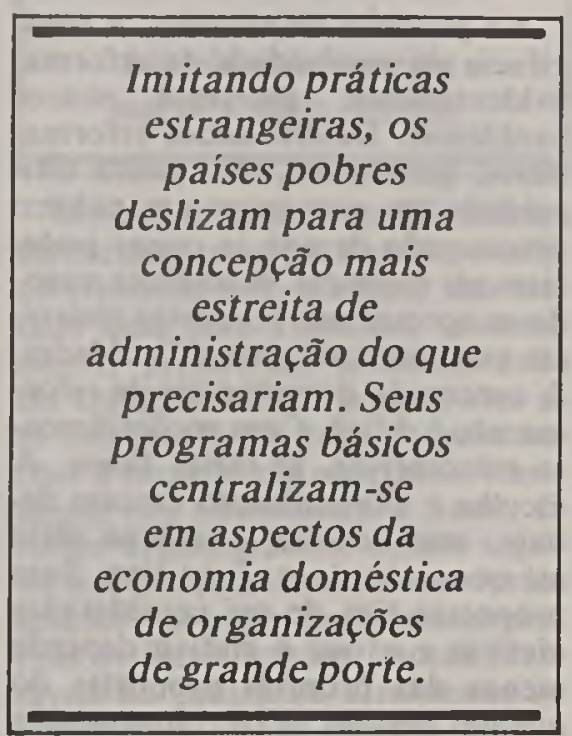

\section{OBJETIVOS INATINGIVEIS}

(a) Os objetivos são desconhecidos, indefinidos ou abstratos. (b) Os objetivos são ideais, perfeições, além da atual capacidade da humanidade.

(c) Uma contenção inadequada é responsável pela tentativa de fazer muita coisa ao mesmo tempo.

(d) $\mathrm{O}$ excesso de contenção reduz a capacidade e amplia a diferença entre a perspectiva e o desempenho.

(e) A otimização de um subsistema mina a otimização do sistema.

(f) São colocadas cargas anormais sobre os administradores sem apoio adequado da sociedade.

(g) A cultura ou infra-estrutura administrativa não tem capacidade para apoiar os administradores na satisfação das expectativas públicas.

(h) Os objetivos administrativos conflitam com outros objetivos da sociedade.

(i) As politicas contradizem os objetivos.

\section{ESTRUTURA OBSTRUTIVA}

(a) O número de componentes é inadequado, sendo excessivo ou insuficiente.

(b) $\mathrm{O}$ arranjo dos componentes é inadequado para a tarefa, sendo excessivamente hierárquico, excessivamente colegial ou antiquado.

(c) As relaçðes entre os componentes são desnecessariamente complicadas.

(d) As comunicações se desarranjam.

(e) São copiados modelos estrangeiros sem apreciação adequada da infra-estrutura de apoio.

(f) Componentes incompativeis e não cooperativos não são separados e não existe um mecanismo para conciliá-los.

\section{DESEMPENHO INADEQUADO}

(a) Os constituintes não sabem o que se espera deles e não tểm desempenho à altura das expectativas.

(b) Os constituintes carecem das qualificações e condições necessárias para cumprirem suas tarefas.

(c) Os constituintes são compostos de membros desleais ou impróprios que sabotam o esforço cooperativo.

(d) Os constituintes carecem de incentivos para um desempenho efetivo.

(e) O talento é desperdiçado. 


\section{IDÉIAS}

(f) A orientação do serviço é deslocada por autoconveniência.

(g) São empregadas inadequadamente a administração cientifica e as ciências da administração.

(h) Não se toma qualquer providência para auto-avaliação, correção de erros e adequada experiência de aprendizado.

A correção do diagnóstico envolve a seleção destas deficiências de sistemas e sua classificação segundo a importância para a ação antes de se decidir sobre um programa de reforma.

\section{PROJETO DE PROGRAMA DE REFORMA}

A reforma administrativa é uma preparação para um futuro imprecisamente previsivel. Antes de projetarem um programa de reforma, os reformadores lêm certa concepção do que querem e esperam que aconteça. Vão adiante na presunção de que poderiam também tentar o máximo logo de saida se tivessem, mais tarde, de modificar suas ambições. É quase inconcebivel que sigam adiante sem uma espécie de plano, pelo menos uma conceituação das idéias de reforma dentro de propostas práticas. Em geral, expressam seus objetivos, identificam suas principais dificuldades e esboçam algumas maneiras de superar a resistência, mas talvez prefiram subestimar as dificuldades e esconder suas intençðes evitando compromissos específicos de manutenção do máximo de flexibilidade. Os planos contingenciais procuram abranger os seguintes elementos:

- Identifiçação dos reformadores e de seus principais apoiadores e um apelo de apoio aos não comprometidos.

- Comprovação do valor, da viabilidade, da praticabilidade e da aceitabilidade das propostas de reforma.

- Prova sobre onde funcionaram propostas similares.

- Estimativa do resultado (geralmente, exagerando as melhorias e omitindo as disfunçðes).

- Pontos em que se prevêem oposição e distorção.

- Promessas de recompensas para aqueles que derem apoio e possiveis ameaças de puniçðes aos oponentes.
- Indicações de acesso a recursos adequados.

- Revelação de instrumentos escolhidos.

Estes elementos constituem o programa no que diz respeito à maioria das pessoas. Somente um pequeno grupo interno conhece sua veracidade e o grau com que ele serve de fachada para extensðes ocultas.

\section{ESTRATÉGIA}

Até que ponto revelar o programa de reforma é uma consideração estratégica relacionada com a melhor maneira de impulsionar as reformas. Assim como a estratégia talvez requeira uma modificação das idéias iniciais, do mesmo modo a insistência dos reformadores em certo programa talvez determine sua estratégia. As relações entre o programa de

\begin{tabular}{|c|}
\hline Poucos reformadores \\
tentaram a \\
auto-avaliação, \\
presumiram êxito \\
e esconderam seus \\
fracassos. Dai os \\
impactos das \\
mudanças terem \\
sido decepcionantes. \\
E deixaram de contar \\
como apoio das \\
maiorias da Nação \\
ou de suas lideranças \\
com poder de decisão. \\
\hline
\end{tabular}

reforma e as possibilidades de sua adoção e execução podem ser resumidas numa série de proposições estratégicas.

1. Quanto maior o alcance dos programas de reforma, menor a probabilidade de adoção e execução e maior a probabilidade de emenda, no caso de adoção.

2. Quanto maior a magnitude da mudança implicita nos programas de reforma, menor a probabilidade de adoção e execução e maior a probabilidade de emenda para reduzir a magnitude.

3. Quanto maior o indice de mudança implicito, menor a probabilidade de adoção e execução e maior a probabilidade de modificação, no caso de adoção.

4. Quanto mais amplas as reformas, menor a probabilidade de adoção e execução e maior a probabilidade de emenda no sentido de uma seqüência mais seletiva.

5. Quanto maior a divisibilidade das reformas, maior a probabilidade de adoção e execução.

6. Quanto maior a revogabilidade das reformas, maior a probabilidade de adoção, mas menor a probabilidade de execução.

7. Quanto menos imediato o efeito das reformas, maior a probabilidade de adoção e menor a probabilidade de execução, exceto sob condicões de crise, quando o maior imediatismo do efeito encarece a adoção e a execução.

8. Quanto maior a compatibilidade das metas ou dos objetivos do programa com os valores e as normas dos adotantes e executores, maior a probabilidade de adoção e execução.

9. Quanto mais visivel a incompatibilidade entre os objetivos de programa e os valores dos adotantes e os executores, menor a probabilidade de adoção e execução.

10. Quanto maior a ambigüidade dos objetivos do programa, maior a probabilidade de adoção e menor probabilidade de execução.

11. Quanto maior a compatibilidade entre as metas do programa, maior a probabilidade de adoção e execução.

12. Quanto maiores os efeitos a longo prazo de um programa, menor a probabilidade de adoção, já que os adotantes preferem opçoses com comprometimento de recursos a curto prazo.

13. Quanto mais alto o relevo (interesse pessoal) das reformas para adotantes e executores em potencial, maior a probabilidade de adoção e execução.

14. Quanto mais reagentes as reformas (em oposição a antecipadoras ou orientadas para o futuro), maior a probabilidade de adoção e execução, já que os adotantes têm menos disposição de comprometer recursos com necessidades menos óbvias ou menos tangiveis.

15. Quanto maior o grau de precedência de metas (metas incluidas em programas anteriores), maior a 


\section{IDÉIAS}

probabilidade de adoção e execução.

16. Quanto maior a compatibilidade dos valores e das normas dos adotantes com os instrumentos da reforma, maior a probabilidade de adoção e execução.

17. Quanto maior a complexidade (ou a dificuldade relativa de compreensão e uso) dos instrumentos da reforma, menor a probabilidade de adoção e execução.

18. Quanto maior a rotina dos instrumentos do programa, maior a probabilidade de adoção e execução.

19. Quanto maiores os recursos requeridos para a execução, menor a probabilidade de adoção e execuçâo, a menos que existam alguns re-cursos (então, é maior a probabilidade de adoção e execução).

20. Quanto maior a participação dos adotantes e dos executores nos processos de reforma, maior a probabilidade de adoção e execução.

21. Quanto maior a dependência de coerção para a execução, maior a probabilidade de execução das reformas.

22. Quanto maiores a incerteza e o risco associados aos instrumentos da reforma, menor a probabilidade de adoção e execução.

23. Quanto maior o uso de critérios de atividade (a qualidade c a quantidade de atividade ou o esforço na execução), para a avaliaçio das reformas, maior a probabilidade de adoção e execuçăo, mas menor a probabilidade de consecuça das metas do programa.

24. Quanto maior a êfase no critério de efetividade (os resultados da atividade relativos aos objetivos) para a avaliaçio das reformas, menor a probabilidade de adoç̃o, mas maior a probabilidade de execuçăo, se adotada.

25. Quanto maior a ênfase na efetividade com otimização (efetividade relativa às metas da reforma em termos de possibilidades) para a avaliação das reformas, menos a probabilidade de adoção, mas maior a probabilidade de execução, se adotada (15).

Estas vinte e cinco generalizaçỏes de tendências refletem a inclinação conservadora contra as reformas e os resultados decepcionantes de programas passados de reforma. Uma

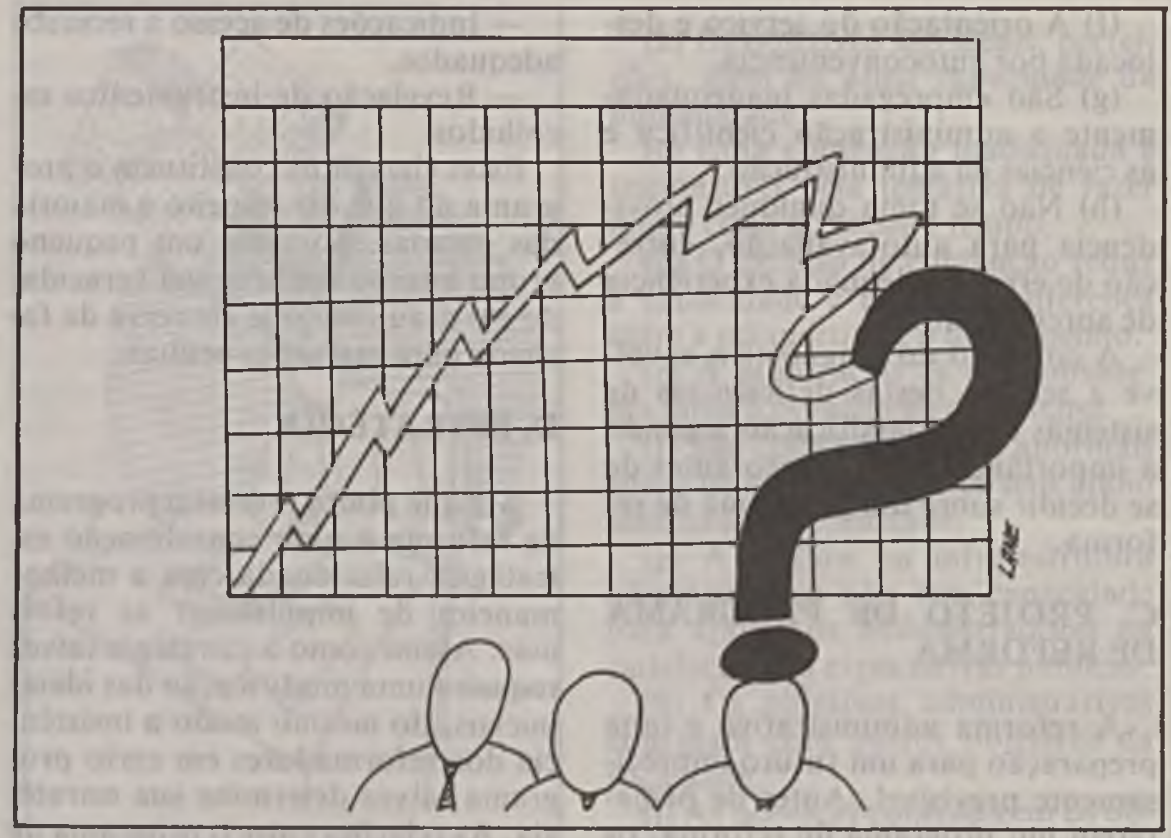

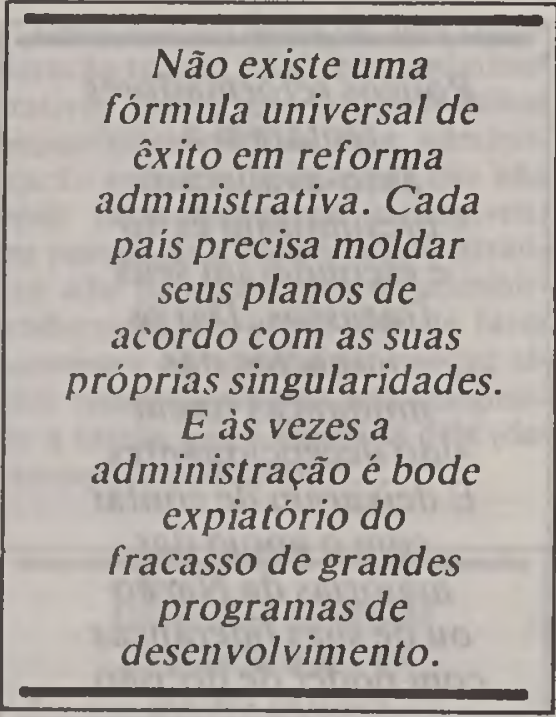

mudança de abordagem poderia invalidar as proposiçðes.

\section{E. A INSTRUMENTAÇĀO}

O número e a variedade dos instrumentos de reforma aumentam com a ampliação das concepçoes administrativas e com o progresso tecnologia administrativa. Os principais instrumentos - a Lei, a formação de instituições, a reorganização, a profissionalização, a elaboração orçamentária e a administração cientifica - permanecem com popularidade. Nas últimas décadas, a eles se juntaram a mecanização, a burocratização ou desburocratizaço, a educação, o treinamento e o desenvolvimento executivo, o desenvolvimento organizacional, as ciências da administração e a descentralização. Mais recentes ainda são o planejamento nacional, os seminários e a assistência técnica internacionais, o armazenamento e a recuperação de dados, a proteção institucionalizada da clientela e as ciências de políticas. Como cada um destes instrumentos está amplamente coberto em outros lugares, a atenção se concentrará na reforma administrativa institucional - o estabelecimento de um órgão investigador permanente para propor reformas a serem executadas por unidades operacionais. Isto inclui órgãos governamentais com "Reforma Administrativa" no título, órgãos governamentais especiais que lidam com um aspecto específico da administração, institutos de patrocinio governamental que realizam pesquisas e educação administrativas assim como servicos consultivos, pesquisas e comissōes de patrocinio governamental com funcionamento ad hoc e órgãos comerciais privados especializados em reforma administrativa.

Apesar da diferença de status, poderes, propósitos e composição, certas generalidades se aplicam a todos estes instrumentos como um grupo. Sem apoio político de alto nivel, eles não são levados muito a sério pelas unidades operacionais, independentemente da qualidade de 


\section{IDÉIAS}

seu trabalho. As unidades operacionais obtêm disposição para trabalhar nas atitudes da elite. Se a liderança do País tem pouco interesse pela administração em posição bai$x a$ entre as prioridades nacionais $\mathrm{e} \dot{\mathrm{e}}$ ambivalente a respeito de reforma, então os órgãos de reforma se vêem realizando exercícios técnicos com pouco impacto sobre o desempenho administrativo. Isto é menos verdadeiro entre as forças-tarefa ad hoc, que dependem menos do apoio da elite do que da aceitação profissional. Com o correr do tempo, o entusiasmo morre e os órgãos, empenhando-se por segurança, passam de macrorreformas para, praticamente, insignificâncias técnicas, experiência limitadas e puras relaçóes públicas a respeito de sua própria importância e significação.

Sua competência depende em grande medida de sua capacidade de atrair e conservar talento criativo como centros de liderança administrativa. As condiçōes necessárias incluem uma massa fundamental de adequados individuos preocupados com reformas e abertos a novas idéias, prontos para articular e impulsionar reformas, expostos a variadas experiências organizacionais e recompensados pela continuidade das inovaçóes. Estes lideres da reforma devem possuir intelecto treinado, certas qualidades (como paixão pelo desenvolvimento humano, propensão para a organização, espirito de experimentaça) e uma visão relativista (16). Os órgãos devem proporcionar uma atmosfera de inovação - estimulo e incentivos para a produção, uma liderança simpática disposta a apoiar os esforços do pessoal, uma administração aberta, acessivel, encorajadora, livre fluxo de informações, tomada de decisões descentralizada e um sistema organizado de reconhecimen10, recompensas e divulgação das inovaçðes. Uma falha importante de muitos órgãos está em que eles não praticam o que pregam.

Para encobrirem defeitos, costumam atenuar sua falta de impacto e justificar suas deficiências. Assumindo uma visão estreita da função administrativa, recusam-se a lidar com as politicas, a Lei ou a moralidade. Adotando um papel puramente investigador-consultivo, recusamse a interferir nas atividades do dia- a-dia. Renunciando a qualquer proficiência especial, recusam-se a entrar em controvérsia aberta ou a apoiar um pessoal de mente firme. Tais bufōes convencem as pessoas que ocupam posiçóes como as suas em outras unidades operacionais de que elas são interferidoras fracas e insignificantes. Gabam-se de sua arma de publicidade (isto é, sua exposição), porém nada mais têm para oferecer e persistem com o mito do escândalo público quando ninguém mais lhes presta qualquer atenção ou quando seus relatórios são esquecidos em horas.

Seus resultados variáveis talvez tenham a ver com composições conirastantes. $\mathrm{Na}$ abordagem de autoridade, os órgãos são guarnecidos de subordinados de confiança simpáticos à liderança atual. São bem familiarizados com os detalhes da situação da reforma e sabem o que é aceitável para as elites. Seu trabalho consciencioso pode ter forte impacto. Mas têm interesse particular pelo status quo e costumam ser favoráveis aos arranjos existen-

\begin{tabular}{|c|}
\hline É preciso saber \\
até que ponto \\
impulsionar a \\
estratégia. As \\
relaçóes entre o \\
programa de reforma \\
e as possibilidades \\
de sua adoção podem \\
ser resumidas numa \\
série de \\
proposiçôes \\
estratégicas. A \\
competência depende \\
do poder de somar.
\end{tabular}

tes nos quais são favorecidos pessoalmente. Não podem admitir que possam ser causa de fracasso. De modo que talvez encubram defeitos óbvios, só revelem falhas insignificantes e, em geral, justifiquem os arranjos existentes. Talvez usem também a oportunidade para acertar contas com inimigos. Excessivamente empenhados no apoio à autoridade existente e excessivamente identificados com a situação, talvez não sejam suficientemente objetivos.

Na abordagem do expert, experts administrativos desinteressados compõem os órgãos de reforma. Presumivelmente objetivos, honestos, confiáveis, podem falhar livremente sem temor ou favor. Sua orientação pode ser rejeitada sem reflexão a respeito de ninguém e as autoridades não estão comprometidas (nem identificadas) com eles. Mas eles talvez nunca cheguem a saber o suficiente a respeito da situação da reforma para fazerem um diagnóstico correto. Talvez tenham desempenho mau ou superficial. Talvez sejam favoráveis a seus remédios de estimação em todas as situações, pertinentes ou não. Tałvez achem que têm de recomendar mudanças radicais para justificar suanomeação ou seu stalus ou sua remuneração. Sendo gente de fora, talvez fiquem sujeitos a um jogo de espera - isto é, talvez, deliberadamente, sejam evitados ou tenham seu trabalho retardado por unidades operacionais sem entusiasmo pela reforma (17).

Gente representativa que apresenta a probabilidade de ser responsável pela execução das propostas é escolhida na abordagem de consenso. Tal gente conhece a situação da reforma em primeira mão e, como tem de executar qualquer acordo a que se chegue, é provável que evite esquemas irreais e fantasias teoricas. Infelizmente, talvez presuma que qualquer critica é uma reflexão sobre seu próprio desepenho e por isto talvez não possa ser fraca. Estas pessoas talvez assumam o papel de consetho de defesa, atuando como porta-vozes de seus respectivos grupos e bloqueando quaisquer mudanças indesejáveis. Talvez não sejam escolhidos os representantes certos ou os melhores representantes e eles talvez nunca cheguem a acordo entre eles mesmos. A experiência talvez formalize divisões existentes e piore as coisas ao institucionalizar campos hostis.

Para superar alguns dos riscos em potencial das outras abordagens, a abordagem da oportunidade recruta o pessoal em todas as fontes, em porçōes variadas, de acordo com a avaliação do talento e da potencialidade de contribuição. Ao mesmo tempo, é feito um convite geral a 


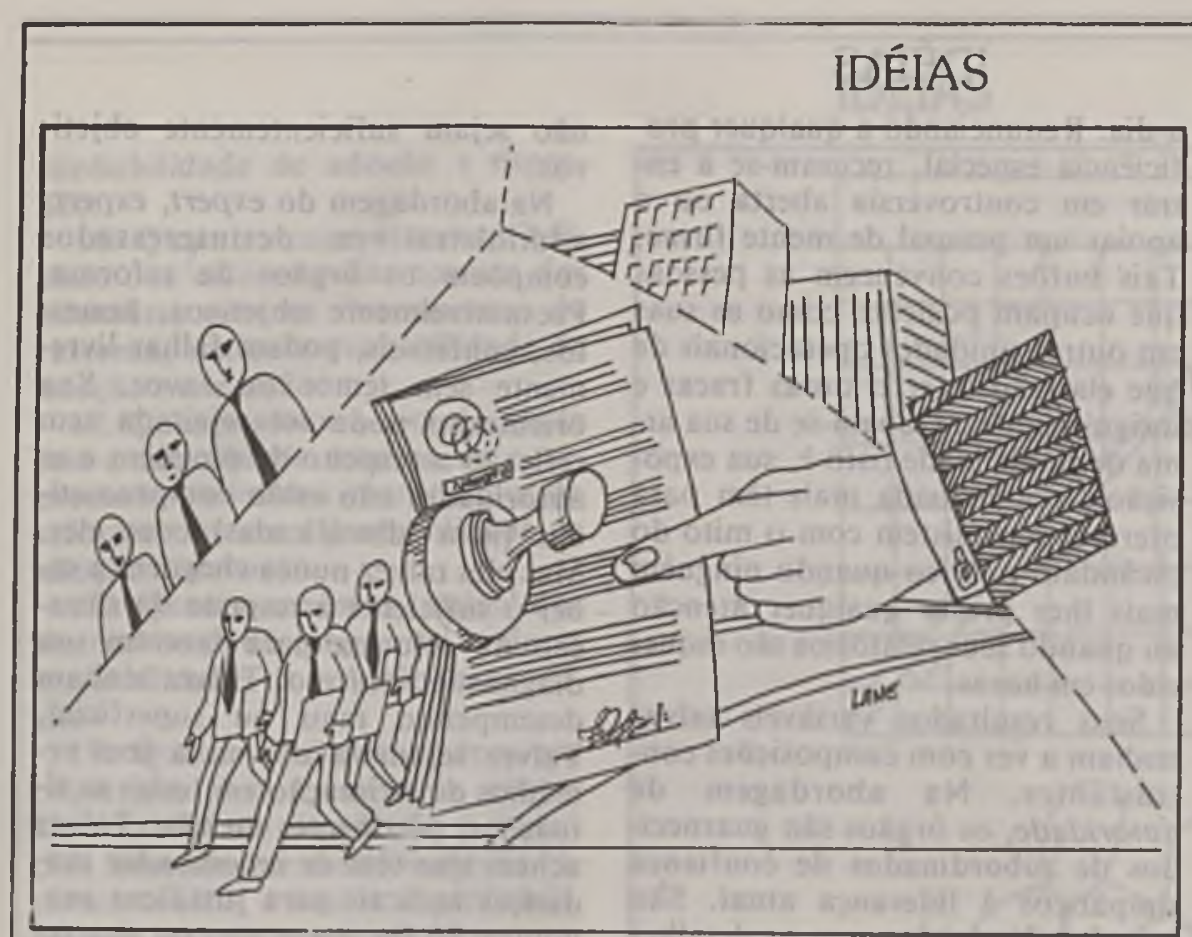

quaisquer pessoas interessadas para que apresentem comentários e sugestões. $\mathrm{O}$ objetivo é combinar conhecimentos e talento e abrir o processo de reforma para quem quer que queira falar, reduzindo assim ao minimo os rumores e temores com uma atuação relativamente aberta. Mas, quanto mais ampla a área de representação, maior a possibilidade de desacordo e divisão a respeito das propostas. Tal representaçảo é de organizaçāo dispendiosa ce leva tempo para chegar a conclusoes. mas dá ênfase às questoes de réforma, dá forma a opinioes superficiais e localiza uma açāo remediadora. Um exemplo frisante desta abordagem incomum foi o Congresso de Reforma Administrativa de 1968. no Irã (18).

Qualquer que seja a abordagem, o órgão de reforma lem lodos os problemas de reforma administrativa, e mais do que isto. Sua própria existência talvez desencoraje arranjos alternativos. Talvez o órgão bloqueie inovaçoes administrativas que não aprove. Se é bem-sucedido, talvez seja refreado, para que ndo pareça um rival excessivamente forte nos assuntos públicos. Se se mostra inadequado, talvez cause dano, por anos, às perspectivas de reforma. Em tempo algum, porém, a autoridade nomeadora - presumivelmente, o Governo - é isentada de responsabilidade pela reforma administrativa em geral pela escolha dos instrumentos em particular.

\section{F. ALIMENTAÇĀO}

Uma vez postos em ação a estratégia c os instrumentos escolhidos, a tarefa final na execução é tomar nota do que está acontecendo ao programa de reforma e determinar se as reformas eståo vigorando. O problema c simplificado quando os defensores da reforma são também os adotantes e executores. A autoiniciativa $\dot{e}$, obviamente, o melhor curso na reforma administrativa,

\begin{tabular}{c}
\hline E possivel que \\
alguns setores \\
assumam a defesa \\
das posições \\
contrárias aos atos \\
de mudanças e \\
surjam porta-vozes \\
dos grupos que \\
desejam impedir o fim \\
das situações já \\
arraigadas. E os \\
resultados podem até \\
desagradar àqueles que \\
apoiam a reestruturação. \\
\hline
\end{tabular}

pois com ela é minima a necessidade de consultar gente de fora, obter apoio da elite, montar campanhas públicas, convencer funcionários conservadores e conceber canais especiais para alimentaçāo de infor- mações. "Todo administrador é seu próprio reformador" é um bom slogan, mas um pouco idealista quanto ao fato de que os administradores talvez sejam causa de impropriedade ou talvez não sejam reformadores competentes ou talvez não tenham tempo, energia e disposição Para devotar às reformas quando têm de ser decididas questôes prementes do momento ou talvez nāo queiram ser seus próprios reformadores, preferindo contratar outros para a tarefa. Apesar disto, é desejável encorajar a auto-iniciativa na reforma administrativa, descentralizar a tomada de decisoes para permitir que as pessoas mais afetadas decidam por elas mesmas sem desordenado retardamento e dar ênfase à correção de erros no ponto certo.

$\mathrm{Na}$ falta de auto-iniciativa - ou quando os lideres procuram monitorar os efeitos da reforma - a alimentação de informações é necessária. O volume necessário de alimentação depende (a) da presença de confiança mútua entre as partes envolvidas, (b) do grau de abertura no processo de reforma e na aderência aos instrumentos escolhidos (por exemplo: os procedimentos legais são, em geral, mais abertos do que os procedimentos orçamentários), (c) as atitudes dos reformadores se eles, realmente, se importam com o que acontece com suas propostas depois da adoção formal ou não, (d) dos critérios de avaliação usados e (e) de quais (e de quem) são as expectativas consideradas. Os três primeiros pontos se explicam por eles próprios. A alimentação só se torna problema quando nảo existe confiança mútua, quando os processos de reforma são secretos e quando os reformadores, realmente, se importam, de fato, com o que acontece depois da adoção. Os reformadores talvez se satisfaçam com qualquer mudança no status quo dentro das linhas de suas concepcões iniciais, aceitando quaisquer afastamentos como o preço da reforma ou talvez possam ser intransigentes, nåo descansando até ficarem satisfeitos por terem ido até onde foi possivel e esgotado todos os recursos. Os perfec-. cionistas entre eles querem investigar as conseqüências, tanto boas quanto más, de fatores nảo previstos e estimar as possibilidades do 


\section{IDÉIAS}

uso da situação transformada como um trampolim para novos programas de reforma. Querem ir além das espécies habituais de informações requeridas para alimentação - estatística, bancos de dados, orçamentos, leis, relatórios, politicas, programas, indicadores administrativos, planos, metas, organogramas, esquemas, pesquisas de opinião e de atitudes, materiais de organização e administração, contratos -, chegando ao que só pode ser descrito como espionagem administrativa e a informações confidenciais, o que lhes dá acesso a informações para antecipação e previsão.

Úma vez decidido um ponto fundamental, a avaliação dos esforços de reforma pode ser feita a vários niveis diferentes. $O$ resultado pode ser comparado com concepçoes iniciais, objetivos aparentes de reforma, intençōes reais, acordos e modificaçðes declarados e resultados possiveis. $\dot{A}$ parte as variadas dificuldades conceituais, cada coisa destas requer um mecanismo de alimentação diferentes. Grande parte deixa de satisfazer às expectativas. Se levamos em consideração somente as opiniōes dos reformadores ou dos instigadores da reforma, há o perigo de distorção. Eles talvez sejam gente de fora, estrangeiros, visilantes, convidados. É provável que sejam aspirantes à elite, jovens, ambiciosos, altamente instruidos, politicamente sensiveis, provavelmente detendo posiçoses influentes ou estreitamente ligados a detentores do poder. Como agentes de mudança, movimentadores sociais, inovadores, ativistas, suas expectativas apresentam a probabilidade de serem superiores às da maioria das pessoas. Mesmo se suas aspiraçðes não forem satisfeitas, os resultados talvez sejam agradáveis para diferentes grupos - elites, conservadores administrativos, reformados, clientela, planejadores de desenvolvimento - por diferentes razōes. A a valiação não é direito exclusivo dos reformadores e dos reformados. O julgamento final deve ficar para "os homens e as mulheres comuns, a quem todo o aparelho administrativo está destinado a servir. E seria, na verdade, precipitado e insensivel um governo que irrefletidamente descartasse suas reaços ou nảo pro- curasse descobrir o que eram aquelas reações"' (19).

\section{REFORMA ADMINISTRATIVA E ADMINISTRAÇÃO DO DE- SENVOLVIMENTO}

Falando-se de um modo geral, embora seja impossivel determinar o que poderia ter acontecido se não houvesse esforços de reforma, è provável que o desenvolvimento seja intensificado por programas de reforma administrativa. Em primeiro lugar, as propostas de reforma desafiam a inércia burocrática e os administradores reacionários e, embora mecanismos de defesa possam

\begin{tabular}{|c|}
\hline Não se pode levar \\
em consideração \\
apenas as opiniões \\
dos que apóiam a \\
reforma. Isto \\
implica no risco de \\
distorçoes. Mas os \\
resultados acabam \\
agradando a maioria \\
dos segmentos sociais, \\
se representarem a \\
maior parcela das \\
aspirações da \\
soçiedade nacional.
\end{tabular}

suprimir temporariamente a mudanca, as coisas nunca podem ser exatamente as mesmas e têm de ser feitos sinais de paz para que a situação seja mantida sob controle. Em segundo lugar, os programas de reforma atraem o talento administrativo empreendedor e fornecem valiosa experiência para uma nova geração de aspirantes administrativos. Em terceiro lugar, os reformadores promovem uma modernização administrativa seriamente necessitada e que apresenta a probabilidade de desencadear uma reação em cadeia nas reformas funcionais à medida que as mudanças de técnicas, habilitaçðes e atitudes em campos especializados parecem mais atingiveis do que, possivelmente, as mudanças mais trabalhosas a serem efetuadas na administração. Em quarto lugar, as forças progressistas construtivas encontram aberturas para seu respeitá- vel talento criativo na solução empirica de problemas, particularmente a espécie apresentada na reforma administrativa. As elites sensiveis procuram recrutar sua ajuda para evitar que elas se juntem a extremistas nos movimentos politi$\cos$ e sociais revolucionários. Em quinto lugar, há menos inventiva, porque o trabalho se realiza com sistemas antiquados, instituições obsoletas, órgãos burocráticos inertes, arranjos inuteis e atitudes conservadoras e qualquer esforço para transformar os sistemas administrativos tem de ser realizado em face da indiferença oficial, da ignorância técni$\mathrm{ca}$, da intransigência politica e da apatia pública.

Este último ponto é especialmente importante. Diante da desarticulação da opinião pública, do segredo administrativo, das instituiçōes autocráticas e dos esforços esporádicos, isolados e descoordenados para melhorar o desempenho, dificilmente haverá qualquer movimento forte em favor da reforma administrativa em qualquer pais e as pessoas que gostariam de ver uma administração melhor "não sabem como fazer com que suas reivindicaç-oes sejam apreciadas ou que medidas práticas tomar" (20). Em muitos paises, o clima é distintamente desfavorável. Onde não há um empenho público significativo na modernizaçăo administrativa, os planos de reforma grandiosos simplesmente "dão aos lideres tradicionais uma oportunidade de posarem de herói a expensas de üma boa direçao administrativa" (21), porque os programas de reforma administrativa requerem mais participação popular do que a maior parte dos outros esforços de desenvolvimento.

E possivel que seja criada uma acearia num pais em desenvolvimenlo ou que a bacia de um rio seja desenvolvida graças a uma breve exportação-importação de recursos econômicos e de know-how técnico. $A$ instalação pode afetar ou beneficiar apenas uma pequena proporça da população. Pode nunca ser vista por muitos. E improvável que seu funcionamento bem-sucedido dependa diretamente da aceitação pública e ainda menos da associação pública com tal funcionamento ou da participação pública nele. A po- 
sição dos projetos de reforma administrativa é diferente. Ao correr de vinte anos, um peso cada vez maior vem sendo atribuido a duas proposições. Primeira: a de que os processos administrativos nacionais estão enraizados na cultura nacional e em valores comunitários e uma mudança em um envolve, às vezes, num processo duplo de causa e efeito, mudança no outro. Segunda: a de que a administração pública e o alheiamento público da administração não são mais compativeis com uma sociedade orientada para um desenvolvimento efetivo. Há um século, a administração pública, na maioria dos países, era, para usarmos um clichê, uma administração de "lei e ordem", com sua obrigação principal restrita à proteção do cidadão contra a desordem doméstica e a agressão externa. Era estritamente limitada. Parava à porta do lar. Dentro, o cidadão continuava senhor. Nas sociedades modernas, a administração penetrou em cada cômodo, çada relação pessoal, cada aspecto da vida. O cidadão não pode impedir a entrada dela. Além do mais, esta administração submetese, freqüentemente como resultado da melhoria da comunicação de massa e do desejo de projetar uma imagem pública atraente, ao cxame e ao julgamento de júri de âmbito nacional. Nesta atmosfera, uma reforma administrativa, para ser bemsucedida, requer, pelo menos, aceitação e uma participaç̃õo do público (22).

Que o apoio público é essencial é bem óbvio quando o processo continuo de reforma administrativa é levado cm conta. Embora certos movimentos, programas e reformadores mudem, a necessidade de reforma continua, pois ainda nåo existc uma administração que não possa ser melhorada. $\mathrm{Na}$ época em que se completa um ciclo, bemsucedido ou nðo, aparecem novos fatores para impulsionar a necessidade em direção diferente e a reforma de forma diferente. Reconhecendo isto, grupos de reforma administrativa da África e da América Latina têm insistido por esforços cuidadosos, concertados entre os paises pobres para combaterem "uma tendência crescente de compartimentalizar os problemas administrativos e procurar solucioná-los em isolamen-

\section{IDÉIAS}
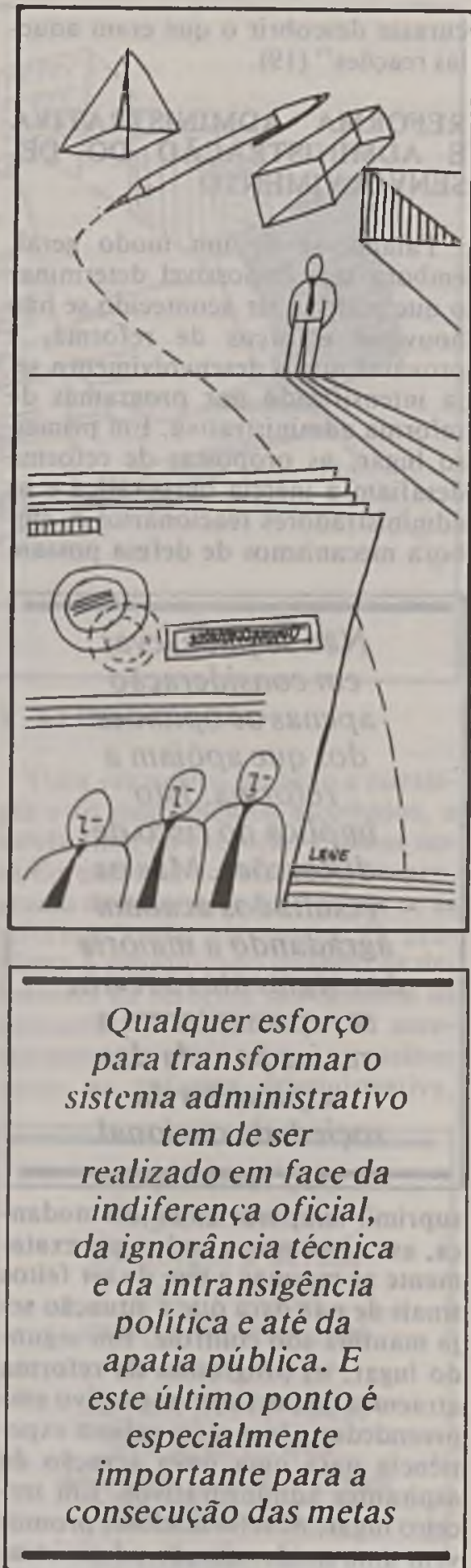

10" (23). Na África, a politica recomendada inclui a criação de um clima favorável de reforma, ampla pesquisa das deficiências adminisIrativas, a preparação de uma série de planos em perspectiva, a médio prazo e anuais, integrados com o planejamento nacional, a institucionalização de reforma através de um mecanismo permanente para a execução, experiências piloto de refor- ma antes da aplicação geral e amplo desenvolvimento do pessoal através de retreinamento em todos os niveis (24). Para a América Latina, a política recomendada é similar, dando ênfase aos apoios políticos, a avaliações realistas dos objetivos e necessidades nacionais, à continuidade do instrumental e das táticas de execução, à inter-relação com o planejamento nacional e aos projetos de desenvolvimento, ampla institucionalização em todos os níveis administrativos, modernização do sistema jurídico e treinamento e motivação dos administradores com vistas à reforma administrativa (25). Mas há advertências de que "a administração pública não pode ficar sujeita a reformas fundamentais muito freqüentes (26) para que não ganhe corpo uma psicose de saturacão, os administradores não negligenciem suas tarefas principais e "fiquem cada vez mais impacientes com a imposição de reformas administrativas e com a proporção de tempo requerida para sua introdução e execução", acabando por levar ao imobilismo administrativo e à revolta contra as inovações administrativas (27).

Os protestos de administradores de que a reforma é excessivamente rápida ou excessivamente trabalhada ou excessivamente perturbadora simplesmente confirmam a justeza da atitude dos reformadores e sua devoção à causa. Mas eles também destacam a essência da reforma administrativa como o esforço para causar "um desenvolvimento possivel ou mais rápido do que é possivel pelos processos naturais de desenvolvimento cultural" e que os esforços de reforma devem ser medidos menos por suas contribuiçðes quantitativas ou até mesmo qualitativas à melhoria da administração do que por sua contribuição à solução de problemas, à criatividade e à inovação e pela transformação da sociedade (28), o que está fadado (e destinado) a colocar tensðes anormais sobre os administradores desenvolvimentistas em sua preocupação com o projeto e construção de sistemas. Afinal de contas, a reforma administrativa faz parte da administração desenvolvimentista, que não somente se preocupa com fazer as coisas funcionar melhor como também "abraça sua preocupação 


\section{IDÉIAS}

mais básica de procurar determinar que espécies de coisas têm probabilidade de funcionar, assim como fazê-las funcionar" (29). Os conflitos entre reformadores administrativoz eadministradores surgem porque eles definem problemas diferentemente, diferem a respeito de manutenção de sistemas e desenvolvimento de sistemas (ou construção de sistemas), analisam o ambiente da tarefa sob perspectivas diferentes (e, possivelmente, com diferentes técnicas), atuam em áreas diferentes de tomada de decisōes, dão impulso a estratégias de desenvolvimento diferentes (provavelmente, opostas) e têm presunções diferentes a respeito da viabilidade e das conseqüências das reformas. Em suma, a administracão desenvolvimentista exige muito mais dos administradores do que a concepção tradicional da funcão administrativa que eles aprenderam na literatura geral de ciência administrativa que reflete atitudes em paises ricos altamente complexos e diferenciados. Exige o máximo dos administradores nos paises incapazes de sustentar a administração em niveis minimos e inaceitáveis, encerrados em códigos juridicos antiquados, obsedados pela imitação das grandes potências, deficientes em talento administrativo ou padecendo de excessiva probreza institucionalizada (30), nos quais a reforma, mesmo que parcial, esporádica, episódica e periódica, é acumulativa na Iransformação e modernização dos sistemas administrativos para fins de desenvolvimento.

\section{NOTA}

O autor apoiou-se extensamente em numerosos casos especificos de reforma administrativa existentes na literatura em geral, muitos dos quais foram usados em Administrative Reform (Aldine Atherton, Chicago, 1969), e também em estudos regionais compilados para o Seminário Inter-regional das Nações Unidas sobre Grandes Reformas Administrativas nos
Paises em Desenvolvimento, realizado pelo Instituto de Estudos sobre Desenvolvimento em Falmer, Brighton, Reino Unido, de 25 de outubro a 2 de novembro de 1971, estudos estes que abrangiam a Argélia, Bolivia, Brasil, Burundi, Ceilão, Chile, Colômbia, Egito, Espanha, Filipinas, França, Gana, India, Indonésia, Iraque, lugoslávia, Japão, Libia, Malásia, México, Nova Zelândia, Niger, Peru, Polônia, Reino Unido, República da Coréia, República Dominicana, Senegal, Somália, União Soviética e Venezuela, mais dois documentos gerais sobre a África e a América Latina.

\section{Bibliografia}

1. Public Administration in the Second United Nations Development Deçade, relatório da Segunda Reuniåo de Especialistas, 16-26 de janeiro de 1971, Divisão de Administração Pública, Departamento de Assuntos Econômicos e Sociais, Naçóes Unidas, Nova lorque, 1971 ST/TAO/M/57, p.4.

2. Ib. p. 11-12.

3. P. Lengyel (organizador da ediçáo), Approaches to the Science of SocioEconomic Development, UNESCO, Paris, 1971, p.9.

4. Divisăo de Administração Pública das Naç̋es Unidas, Appraising Administrative Capability for Development, Nova lorque, 1969, ST/TAO/M/46, p.8.

5. Ib., p. 67-68.

6. "Basic Considerations on AdminisIrative Capability for Development in Lain America", Public Administration Newsletter. Divisāo de Administraçăo Pública das Naçóes Unidas, Nova lorque, N2 42, outubro de 1971, p. 15.

7. N. K. Mukarii, "Formulation of Administrative Reform Strategies", Seminário Inter-regional das Naçoes Unidas sobre Grandes Reformas Administrativas nos Paises em Desenvolvimento, 1971, ESA/PA/, Reuniảo I/4, p. 19.

8. G. Burgess, "Technical Cooperation as a Source of Ideas, Models and Assistance in Administrative $\mathrm{Re}$ form". Seminário Inter-regional das Nacóes Unidas sobre Grandes Reformas Administrativas nos Paises em Desenvolvimento, 1971, ESA/PAl, Reuniāo $1 / 17$, p. 20.

9. C. K. Wilbur, The Soviet Model and Under Developed Countries, Chapel Hill, University of North Carolina Press, 1969. p. 13.

10. Public Administration in the Second United Nations Decade, op. cit., p. 36 .

11. D. E. Awolwi, "Major Administrative Reforms in Developing Countries: Review of Ghanaian Experiences Through Analysis of Significant Case Studies", Seminário Inter-regional das Naçoes
Unidas sobre Grandes Reformas Administrativas nos Paises em Desenvolvimento, 1971, ESA/PA/Reuniảo I/15, p. 15-16.

12. A. Adedeji, "Formulating Administrative Reform Strategies in Africa", Seminário Inter-regional das Naçoes Unidas sobre Grandes Reformas Administrativas nos Paises em Desenvolvimento, 1971, ESA/PA/Reuniāol/10, p.9.

13. W. Jiménez-Castro, "Strategies of Administrative Reform in Latin America", Seminário Inter-Regional das $\mathrm{Na}$ cóes Unidas sobre Grandes Reformas Administrativas nos Paises em Desenvolvimento, 1971, ESA/PA/Reuniăo 1/8, p. 3-4.

14. I. Y. Sayed, "Administrative Development: A Conceptual Orientation and Issues for Research", Seminário Interregional das Naçōes Unidas sobre Grandes Reformas Administrativas nos Paises em Desenvolvimento, 1971, ESA/PA/Reunião I/25, p.1-2.

15. Adaptado e modificado do trabalho de R. Backoff e G. E. Caiden "Operationalizing Administrative Reform for Better Governmental Performance", Sociedade Norte-Americana de Administração Pública, Conferência de Denver, 18-21 de abril de 1971

16. Hahn Been Lee, "The Role of Leadership in Administrative Reform". Seminário Inter-regional das Naçoes Unidas sobre Grandes Reformas Administrativas nos Paises em Desenvolvimen10, 1971, ESA/PA, Reuniāo 1/2, p. 18-22.

17. D. E. Awotwi, op. cit., p. 23.

18. H. Pirnazar, "Appraisal of the Results and Consequences of Major Administrative Reforms", Seminário Interregional das Naç-oes Unidas sobre Grandes Reformas Administrativas nos Paises em Desenvolvimento", 1971, ESA/PA/Reuniăol/1, p. 24-26.

19. Ib., p. 24.

20. A. Adedeji, op. cit., p. 22.

21. R. B. Tadena, "The PostIndependence Experience of the Philippines in Major Administrative Reforms in Developing Countries", 1971. ESA/PA/Reuniăo //40, p. 34.

22. G. Burgess, op. cit., p. 4.

23. A. Adedeji, op. cit., p. 19.

24. Ib., p. 23-24.

25. W. Jiménez-Castro, op. cit., p. 1719.

26. Z. Rybicki, "Decentralization and Its Significance for Reforms of Public Administration" Seminário Inter-regional das Naços Únidas sobre Grandes Reformas Administrativas nos Paises em Desenvolvimento, 1971, ESA/PA/Reunião $1 / 21$, p. 20.

27. H. L. Laframboise, "Administrative Reform in the Federal Public Service: Signs of a Saturation Psychosis". Canadian Public Administration, Vol. 14, $N^{2} 3$, quarto trimestre de 1971, p. 303-325.

28. I. Y. Sayed, op. cit., p. 2-3.

29. W. Siffin, "Development Administration as a Strategic Perspective". Seminário Inter-regional das Naçoes Unidas sobre Grandes Reformas AdminisIrativas nos Paises em Desenvolvimen10, 1971, ESA/PA/Reuniăo 1/49, p. 4.

30. G. Burgeses, op. cit., p. 8-11 